Article

\title{
Dry Hydrogen Production in a Tandem Critical Raw Material-Free Water Photoelectrolysis Cell Using a Hydrophobic Gas-Diffusion Backing Layer
}

\author{
Stefano Trocino ${ }^{1, *(D)}$, Carmelo Lo Vecchio ${ }^{1}\left(\mathbb{D}\right.$, Sabrina Campagna Zignani ${ }^{1}$, \\ Alessandra Carbone ${ }^{1}\left(\mathbb{D}\right.$, Ada Saccà ${ }^{1}(\mathbb{D})$, Vincenzo Baglio ${ }^{1}(\mathbb{D})$, Roberto Gómez ${ }^{2} \mathbb{D}$ \\ and Antonino Salvatore Aricò ${ }^{1}$ (D) \\ 1 Consiglio Nazionale delle Ricerche, Istituto di Tecnologie Avanzate per l'Energia "Nicola Giordano", \\ CNR-ITAE, Via Salita Santa Lucia sopra Contesse, 5-98126 Messina, Italy; \\ carmelo.lovecchio@itae.cnr.it (C.L.V.); sabrina.zignani@itae.cnr.it (S.C.Z.); \\ alessandra.carbone@itae.cnr.it (A.C.); ada.sacca@itae.cnr.it (A.S.); vincenzo.baglio@itae.cnr.it (V.B.); \\ antonino.arico@itae.cnr.it (A.S.A.) \\ 2 Departament de Química Física i Institut Universitari d’Electroquímica, Universitat d'Alacant, Apartat 99, \\ 03080 Alicante, Spain; Roberto.Gomez@ua.es \\ * Correspondence: stefano.trocino@itae.cnr.it; Tel.: +39-090-624-270
}

Received: 6 October 2020; Accepted: 10 November 2020; Published: 13 November 2020

check for updates

\begin{abstract}
A photoelectrochemical tandem cell (PEC) based on a cathodic hydrophobic gas-diffusion backing layer was developed to produce dry hydrogen from solar driven water splitting. The cell consisted of low cost and non-critical raw materials (CRMs). A relatively high-energy gap (2.1 eV) hematite-based photoanode and a low energy gap $(1.2 \mathrm{eV})$ cupric oxide photocathode were deposited on a fluorine-doped tin oxide glass (FTO) and a hydrophobic carbonaceous substrate, respectively. The cell was illuminated from the anode. The electrolyte separator consisted of a transparent hydrophilic anionic solid polymer membrane allowing higher wavelengths not absorbed by the photoanode to be transmitted to the photocathode. To enhance the oxygen evolution rate, a $\mathrm{NiFeO}_{X}$ surface promoter was deposited on the anodic semiconductor surface. To investigate the role of the cathodic backing layer, waterproofing and electrical conductivity properties were studied. Two different porous carbonaceous gas diffusion layers were tested (Spectracarb ${ }^{\circledR}$ and Sigracet ${ }^{\circledR}$ ). These were also subjected to additional hydrophobisation procedures. The Sigracet $35 \mathrm{BC}{ }^{\circledR}$ showed appropriate ex-situ properties for various wettability grades and it was selected as a cathodic substrate for the PEC. The enthalpic and throughput efficiency characteristics were determined, and the results compared to a conventional FTO glass-based cathode substrate. A throughput efficiency of $2 \%$ was achieved for the cell based on the hydrophobic backing layer, under a voltage bias of about $0.6 \mathrm{~V}$, compared to $1 \%$ for the conventional cell. For the best configuration, an endurance test was carried out under operative conditions. The cells were electrochemically characterised by linear polarisation tests and impedance spectroscopy measurements. X-Ray Diffraction (XRD) patterns and Scanning Electron Microscopy (SEM) micrographs were analysed to assess the structure and morphology of the investigated materials.
\end{abstract}

Keywords: water splitting; photoelectrolysis cell; photoelectrochemical cell; carbonaceous gas diffusion layer; green hydrogen; dry hydrogen; semiconductor; solar fuel; non-critical raw materials; solar-to-fuel efficiency 


\section{Introduction}

The existence of several concerns related to the increasing energy demand and the related environmental crisis [1-6] indicates the need to identify innovative, effective and low cost solutions. Photoelectrochemical water splitting (PWS) [7-25] is recognised as a promising strategy and it attracts particular interest for storing solar energy into the chemical bonds of hydrogen as fuel [26-28], which can be further utilised in fuel cells [29-34], internal combustion engines and to progressively decarbonize industrial processes [35-39].

To achieve high solar to hydrogen (STH) conversion efficiencies [40,41] in practical photoelectrochemical (PEC) cells, the choice of photoelectrodes and the cell configuration (one or two photoelectrodes) are of great importance $[7,26,28]$. A single-photoelectrode PEC configuration includes one semiconductor (working as either photocathode or photoanode) and one standard metallic (dark) electrode (e.g., Pt). Ideally, the semiconductor should have an appropriate bandgap and band structure to capture a large portion of the solar spectrum while providing sufficient potential to drive the overall water splitting reaction, as well as excellent charge transport properties and long-term stability during operation [42-50]. Despite the fact that many materials have been explored over nearly half a century, there is currently no single material that can fulfil all these requisites. Since overall water splitting consists of two half-reactions, i.e., water oxidation to oxygen and reduction to hydrogen, it is natural to use a two-photoelectrode configuration to maximize both processes with the cell illuminated from the higher energy gap semiconductor (photoanode in the present case). The longer wavelength photons that are not absorbed by the top large band gap absorber are transmitted to and harvested by the bottom low band gap absorber. Owing to band bending, the photogenerated electrons in p-type photocathodes and holes in n-type photoanodes migrate toward the semiconductor-electrolyte interface to reduce and oxidize water, respectively. In parallel, photogenerated holes in the photocathode and electrons in the photoanode are transferred to the external circuit and recombine at the Ohmic back-contact that connects both photoelectrodes. As each material is responsible for the relevant half reaction of water splitting, the tandem system allows the use of small bandgap material and relaxes the stringent requirement of band edge positions to straddle the water redox potentials $[7,19,26,28,51-57]$. Therefore, a PEC tandem device can achieve potentially higher efficiency than a single absorber system, with large solar spectral coverage and a wide window of suitable materials to choose. It is generally accepted that such a tandem device can yield a theoretical STH efficiency over $20 \%$. With the aim of achieving high efficiency, the optimal top and bottom semiconductor absorbers, in a tandem device, are selected with bandgaps of approximately $1.6-1.8 \mathrm{eV}$ and $0.9-1.2 \mathrm{eV}$, respectively. A maximum STH efficiency of $\sim 27 \%$ was predicted using the $1.7 / 1.1 \mathrm{eV}$ bandgaps combination, which can cover the major portion of solar spectrum with a proper matching between the two photoelectrodes. However, no materials and cell configurations fully satisfy so far, all the stringent requirements for practical application, including appropriate stability, straightforward separation of the produced gases, gas dryness, low-cost characteristics and scalable module manufacturing. All these aspects still make the design of the PEC system quite challenging [58,59] and indicate the need to address towards novel solutions.

For what concerns the backing layer of the top high-energy gap photoanode of the PEC cell, the main requisites are a high transmittance in combination with a high conductivity and proper work function. Usually, the anodic semiconductors are deposited on a conductive transparent glass: fluorine-doped tin oxide (FTO), indium doped tin oxide (ITO) or antimony tin oxide (ATO). These coatings are deposited by various method as chemical vapor deposition, reactive RF sputtering, evaporation, atomic layer epitaxy, spray pyrolysis and sol-gel processes. Whereas, with regards the bottom photocathode backing layer, the most important requirements are high conductivity and proper work function if the intention is to use direct illumination only and no diffusive light. Thus, in this case, it is possible to use a dark metallic-type substrate with proper work-function to avoid junction effects [60-67].

In a previous paper [7], a PEC composed by a hematite-based photoanode and a cupric oxide-based photocathode, both deposited on a transparent FTO glass, was investigated. The addition of $\mathrm{NiFeO}_{X}$ 
to the hematite photo-electrode allowed to improve the performance of the PEC [7]. The maximum value of enthalpy efficiency was $0.53 \%$ using an external bias driven approach. An almost transparent (in the wavelength range of interest) hydrophilic anionic solid polymer electrolyte membrane, Fumatech FAA $3^{\circledR}[68]$, was used for allowing ion migration and the evolved gases. The membrane is hydrophilic and when hydrated also acts a water reservoir for the cell. This was also useful to enhance the durability of the cell compared to conventional corrosive liquid electrolytes such as caustic solutions. This approach was particularly effective to mitigate the corrosion of the $\mathrm{CuO}$ semiconductor. A ionomer dispersion, derived from the same polymer, were used to extend the reaction interface with the semiconductors' surface [28].

Using this configuration, the cathode output stream, where the hydrogen evolution reaction (HER) takes place, was a mixture of hydrogen and water. Dry hydrogen is required in most applications. The production of wet hydrogen thus requires a fuel treatment (e.g., the gas flow through a water condenser and a downstream dehumidification step, e.g., a zeolite bed that requires periodic regeneration), outside the cell with a complex balance of plant. An innovative idea is to obtain dry hydrogen directly from the cathodic output stream of the PEC cell. Complementary to the membrane, which separates hydrogen from oxygen, a conductive hydrophobic backing layer [69] can separate hydrogen from water. The cathodic semiconductor can be deposited on an electrically conductive porous carbonaceous substrate made hydrophobic by specific treatments and additives. The outer part of the backing layer electrode substrate shall be made hydrophobic and porous to facilitate hydrogen escape while avoiding water permeation. One aspect of this concept is in a certain way similar to that used in phosphoric acid fuel cells, where no leaching of free acid is occurring but only gas flow is allowed through the hydrophobic layer. Another aspect is related with establishing a good ohmic contact between the cathodic semiconductor and the current collector by selecting graphitic-type backings with suitable work-function to avoid any junction occurrence [70-74].

This work addresses for the first time the use of a porous hydrophobic backing layer in a PEC cell to allow production of dry hydrogen and increase system simplicity. Moreover, the components involved in this device do not include any material listed in the EU-CRM list 2020 [75]. In particular, neither precious metals, nor phosphides, nor fluorinated membranes etc. are involved in this photoelectrolysis cell concept.

Initially two different cathodic substrates, meeting the above requirements, were studied: a gas diffusion layer (GDL) carbon paper (Spectracarb ${ }^{\circledR}$ 2050A-1550) and a non-woven carbon paper with microporous layer (MPL) that was polytetrafluoroethylene (PTFE) treated up to a $5 \%$ content (Sigracet $35 \mathrm{BC}^{\circledR}$ ). These two candidates were additionally treated in subsequent hydrophobisation steps with fluorinatedethylenepropylene (FEP). Afterwards, the obtained substrates were investigated in terms of FEP uptake, electrical conductivity and contact angle, to preliminary evaluate the effective possibility of using them as cathodic backing layers. Beside the appropriate porosity, it was necessary to determine the right trade-off between a high electrical conductivity, especially on the side where the cathode is deposited, and a high hydrophobisation grade in the outer side of the backing layer to avoid the water permeation but only gas. The most promising substrate, Sigracet ${ }^{\circledR}$, originally containing $5 \%$ of PTFE ("as received") and further hydrophobised by a FEP treatment showing thus different FEP uptakes (e.g., $7 \%$ and $15 \%$ of FEP) were investigated in a complete tandem cell configuration. To compare these results with the state of the art, an FTO glass cathodic substrate was also examined.

For these PECs, only the cathode substrate was varied while the other components remained unchanged.

The tandem cell architecture thus consisted of:

- $\quad$ photoanode: glass $+\mathrm{FTO}+\mathrm{Fe}_{2} \mathrm{O}_{3}+\mathrm{NiFeO}_{\mathrm{X}}+$ ionomer

- $\quad$ electrolyte: transparent FAA- $3^{\circledR}$ anionic solid polymer membrane

- photocathode: ionomer $+\mathrm{CuO}+$ conventional backing layer (FTO + glass) or porous hydrophobic backing layer $\left(\right.$ Sigracet $\left.^{\circledR}\right)$ or (Sigracet ${ }^{\circledR}+$ FEP addition) 
In the investigated PEC device, oxygen is just vented to external environment through the overall anode interface with the external atmosphere. Linear polarisation measurements, covering a wide region of cell potentials, from the spontaneous photo-voltage region to the external bias driven region, were carried out for the various cathodic substrates. Enthalpy efficiency and throughput efficiency curves were obtained. Besides, electrochemical impedance spectroscopy tests were carried out for the PECs to understand the effects of cathodic substrates in term of series, polarisation and total resistances. For the best performing PEC, it was carried out a potentiostatic endurance test.

An X-ray diffraction (XRD) analysis of the anodic and cathodic semiconductors, electrode substrates and combination of both, was carried out. Moreover, the entire photocathode and the Sigracet ${ }^{\circledR}$ gas diffusion layers were investigated by scanning electron microscopy (SEM) micrographs.

\section{Results and Discussions}

\subsection{Characterisation of Gas Diffusion Layers}

Spectracarb ${ }^{\circledR}$ and Sigracet $35 \mathrm{BC}^{\circledR}{ }^{\circledR}$ commercial samples were selected as porous carbonaceous backing layers for the photocathode. Spectracarb ${ }^{\circledR}$ is essentially a carbon fiber paper. Sigracet $35 \mathrm{BC}^{\circledR}$ consists of PTFE-treated carbon fiber paper and microporous carbon black layer (MPL). The side containing the carbon black layer is of specific interest for $\mathrm{CuO}$ deposition, avoiding that part of the $\mathrm{CuO}$ is incorporated into the macroporous structure made of carbon fibers. Whereas the back porous carbon fiber structure is useful for the gas diffusion into the rear of the PEC cell facilitating gas collection. The carbonaceous gas diffusion layers were subjected to waterproofing procedures and investigated to correlate diving time and FEP uptake with relevant properties.

Figure 1a shows that the "full immersed" Spectracarb ${ }^{\circledR}$ sample had a higher increase of FEP uptake with respect to the "one-layer" sample i.e., a sample that was put in contact with the FEP solution only on one side. For the fully immersed samples, after $60 \mathrm{~s}$ of immersion time, the FEP uptake was $37 \mathrm{wt} \%$; after $120 \mathrm{~s}$, a further uptake to $51 \mathrm{wt} \%$ was observed with a saturation behaviour fat $54 \mathrm{wt} \%$ of FEP uptake, after $300 \mathrm{~s}$. For, the sample that was immersed only on one side, after $60 \mathrm{~s}$, the FEP uptake was $12 \mathrm{wt} \%$, after $120 \mathrm{~s}$ it was $19 \mathrm{wt} \%$ and after $300 \mathrm{was} 27 \mathrm{wt} \%$ Concerning Sigracet ${ }^{\circledR}$, in the fully immersed sample, the FEP uptake after $60 \mathrm{~s}$ was $7 \mathrm{wt} \%$, after $120 \mathrm{~s}$, it was $9 \mathrm{wt} \%$, and $15 \mathrm{wt} \%$ after $300 \mathrm{~s}$. In the Sigracet ${ }^{\circledR}$ one-layer immersed sample (in this case it was subjected to waterproofing only the side with the microporous layer), the FEP uptake was $3 \mathrm{wt} \%$ after $60 \mathrm{~s}, 4 \mathrm{wt} \%$ after $120 \mathrm{~s}$ and $7 \mathrm{wt} \%$ after $300 \mathrm{~s}$.

Figure $1 \mathrm{~b}$ shows a plot of electrical conductivity vs diving time. For the Spectracarb ${ }^{\circledR}$ sample, the electrical conductivity was $20 \mathrm{~S} \mathrm{~cm}^{-1}$ without any treatment. After treatment with FEP, it was registered an important decrease of conductivity to about $5 \mathrm{~S} \mathrm{~cm}^{-1}$ quite independently from immersion time, both for full and for one-layer immersion, whereas, for the Sigracet ${ }^{\circledR}$ substrates, the conductivity decreased from about $30 \mathrm{~S} \mathrm{~cm}^{-1}$, in the one-layer immersed sample, to about $10 \mathrm{~S} \mathrm{~cm}^{-1}$ quite independently from the immersion time. In the full-immersed sample, the conductivity decreased to $27 \mathrm{~S} \mathrm{~cm}^{-1}$ after $60 \mathrm{~s}$ of immersion time, $20 \mathrm{~S} \mathrm{~cm}^{-1}$ after $120 \mathrm{~s}$ of immersion time and $13 \mathrm{~S} \mathrm{~cm}^{-1}$ after $300 \mathrm{~s}$ of immersion time.

The contact angle provides a measure of the degree of hydrophobicity for a specific surface. The contact angle can vary between $0^{\circ}$ (complete or perfect wettability) and $180^{\circ}$ (no wettability). The variation of the contact angle as a function of the FEP uptake is shown in Figure 1c. For one-layer immersed Spectracarb ${ }^{\circledR}$ and Sigracet ${ }^{\circledR}$, the contact angle was constant with the increase of the FEP uptake. For Sigracet ${ }^{\circledR}$, it was about $146^{\circ}$, while, for the Spectracarb ${ }^{\circledR}$ about $126^{\circ}$. In the case of "fully-immersed" Spectracarb ${ }^{\circledR}$ the contact angle increased to $146^{\circ}$ for $54 \mathrm{wt} \%$ of FEP uptake. For the "fully-immersed" Sigracet ${ }^{\circledR}$ the contact angle started from $146^{\circ}$ for the bare sample and increased to $156^{\circ}$ for $15 \mathrm{wt} \%$ of FEP uptake.

Figure 2 shows two photographs of a water drop deposited on the two different gas diffusion layers "as received". In the Sigracet ${ }^{\circledR}$ sample, the water drop was deposited on the MPL side. Figure 2a,b 
show the water drop immediately after its deposition. The drop on the Spectracarb ${ }^{\circledR}$ carbon paper has a lenticular shape (lower contact angle), whereas, on the Sigrace ${ }^{\circledR}$ is like a sphere (higher contact angle), this indicate a higher hydrophobicity of Sigracet ${ }^{\circledR}$. Also, $1800 \mathrm{~s}$ after the deposition (Figure $2 \mathrm{c}, \mathrm{d}$ ), such behaviour was confirmed. The water drop on the Spectracarb ${ }^{\circledR}$ is slightly more depressed, whereas that on the Sigracet ${ }^{\circledR}$ maintained the previous characteristics.
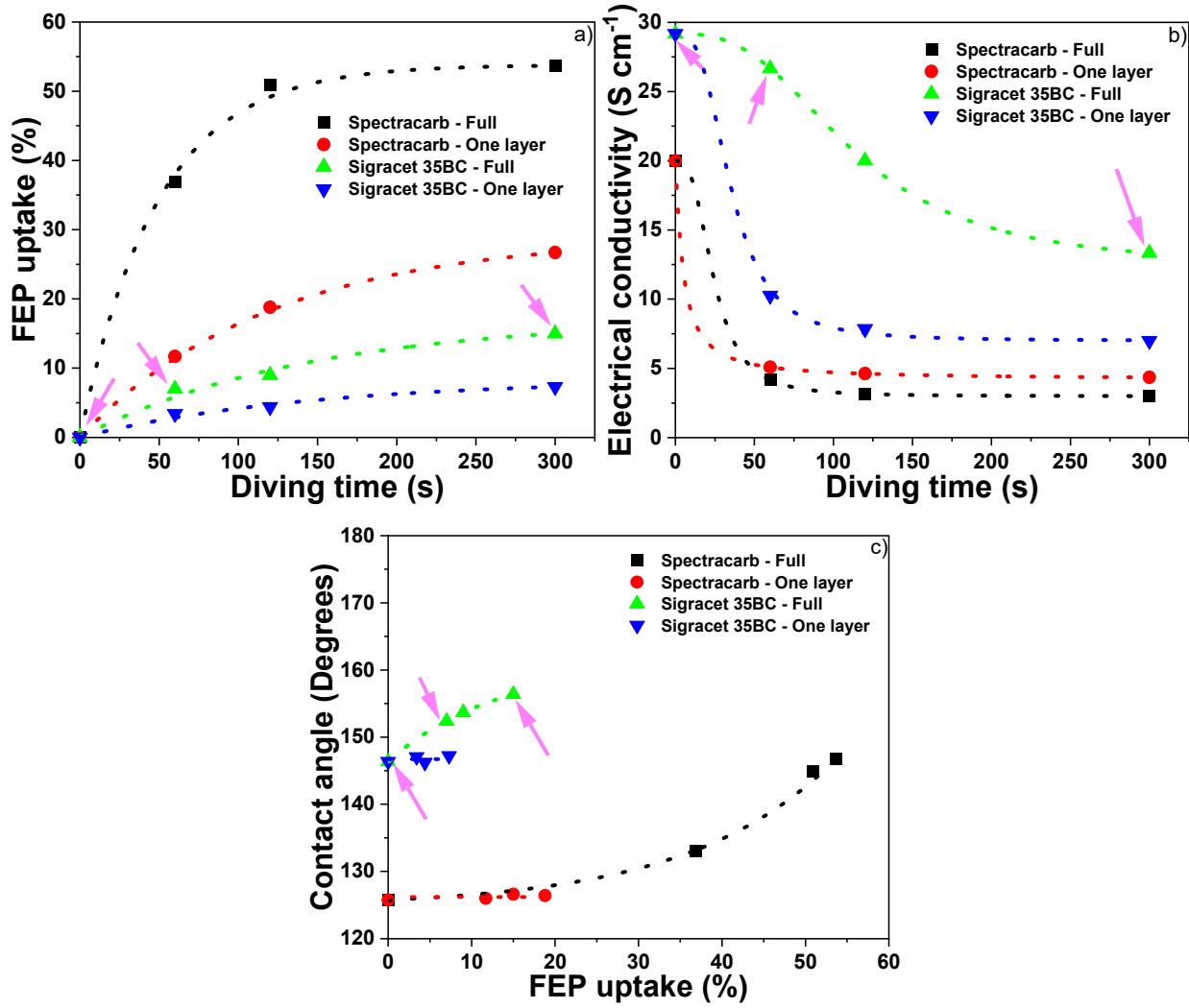

Figure 1. FEP uptake vs immersion time (a), electrical conductivity vs immersion time (b), contact angle top layer vs immersion time (c) of different gas diffusion layers under different hydrophobisation conditions.

a)

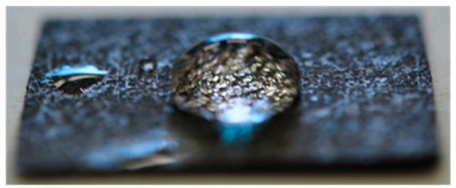

c)

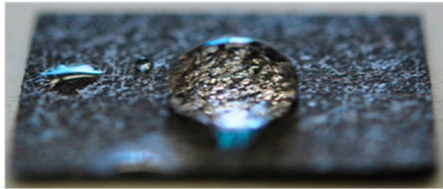

e)

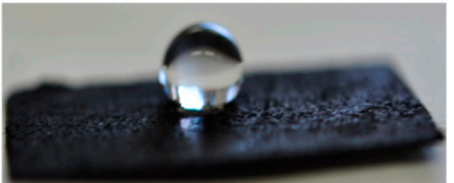

b)

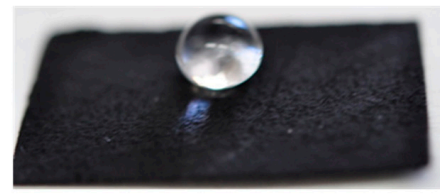

d)

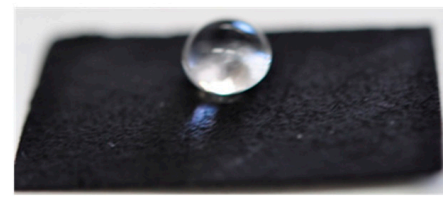

f)

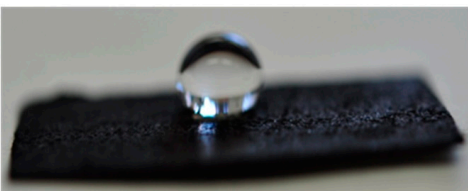

Figure 2. Pictures of a water drop on two gas diffusion layers: Spectracarb ${ }^{\circledR}$ (on the left) and Sigracet $35 \mathrm{BC}^{\circledR}$ (on the right) after $0 \mathrm{~s}(\mathbf{a}, \mathbf{b})$ and after $1800 \mathrm{~s}(\mathbf{c}, \mathbf{d})$. Sigracet $35 \mathrm{BC}^{\circledR}+$ FEP $7 \%$ after $0 \mathrm{~s}(\mathbf{e})$ and after $1800 \mathrm{~s}$ (f). 
A similar comparison for the Sigracet ${ }^{\circledR}$ with FEP addition (FEP $7 \mathrm{wt} \%$ ) at different times is shown in Figure 2e,f and Figure S1 (Supplementary Information). The shape of the water drop was even more spherical with the higher content of FEP corresponding to a larger contact angle as reported above.

According to the proper trade-off between conductivity and hydrophobicity, the Sigracet ${ }^{\circledR}$ carbon paper was selected as gas diffusion backing layer for the $\mathrm{CuO}$ photocathode in tandem photoelectrochemical cells. Furthermore, to investigate the influence of the waterproofing condition on the PEC properties, three FEP uptake characteristics were selected for the "full-immersed" sample i.e., bare $0 \mathrm{wt} \%$ of FEP ( $5 \mathrm{wt} \%$ of PTFE), $7 \mathrm{wt} \%$ and $15 \mathrm{wt} \%$ of FEP.

\subsection{PEC Operation and Cathodic Semiconductor and Substrate Physico-Chemical Characterisation}

Figure 3 shows the concept of the photoelectrochemical cell with an FTO glass as a cathodic substrate (Figure 3a), with a porous hydrophobic carbonaceous gas diffusion layer (Figure 3b) and a photograph of the PEC, with a GDL as cathodic support (Figure 3c).

According to the selected configuration in both cases (FTO or GDL backing), the PEC is able to capture a significant portion of the solar energy [76-78]. The photoanode is directly exposed to the solar irradiation and absorbs higher energy photons according to its energy gap of $2.1 \mathrm{eV}$ $(\lambda<600 \mathrm{~nm})$, whereas the underlying photocathode, exposed to the light transmitted through the transparent polymer electrolyte membrane, absorbs lower energy photons with a band gap of $1.2 \mathrm{eV}$ $(600 \mathrm{~nm}<\lambda<1000 \mathrm{~nm})[7,28]$.

The incident light on the $\mathrm{Fe}_{2} \mathrm{O}_{3}$ photoanode and the wavelengths transmitted to the $\mathrm{CuO}$ photocathode with photon energy larger than the semiconductors' energy gaps generate electron-hole pairs. A scheme for the photogeneration of electrons and holes for the semiconductors used in this work is reported in [7]. The photoconversion reactions are reported below for the alkaline environment produced by the hydrophilic anionic FAA-3 membrane and ionomer previously treated with a $1 \mathrm{M}$ $\mathrm{KOH}$ solution:

Photogeneration:

$$
2 h v \rightarrow 2 \mathrm{e}^{-}+2 \mathrm{~h}^{+}
$$

Anode-oxygen evolution reaction:

$$
2 \mathrm{OH}^{-}+2 \mathrm{~h}^{+} \rightarrow \frac{1}{2} \mathrm{O}_{2}(\mathrm{~g})+\mathrm{H}_{2} \mathrm{O}
$$

Cathode—hydrogen evolution reaction:

$$
2 \mathrm{H}_{2} \mathrm{O}+2 \mathrm{e}^{-} \rightarrow \mathrm{H}_{2}(\mathrm{~g})+2 \mathrm{OH}^{-}
$$

PEC—overall water splitting:0

$$
\mathrm{H}_{2} \mathrm{O} \rightarrow \mathrm{H}_{2}(\mathrm{~g})+\frac{1}{2} \mathrm{O}_{2}(\mathrm{~g})
$$

By comparing Figure 3a,b, it is clear-cut that the introduction of the gas diffusion layer in the PEC, may allow to have a dry hydrogen production directly at the cathodic output stream. As shown by the contact angle measurement, water is unable to permeate through the hydrophobic carbonaceous backing layer. Thus, the cell assembly can be summarized as reported in Figure 3a,b. 


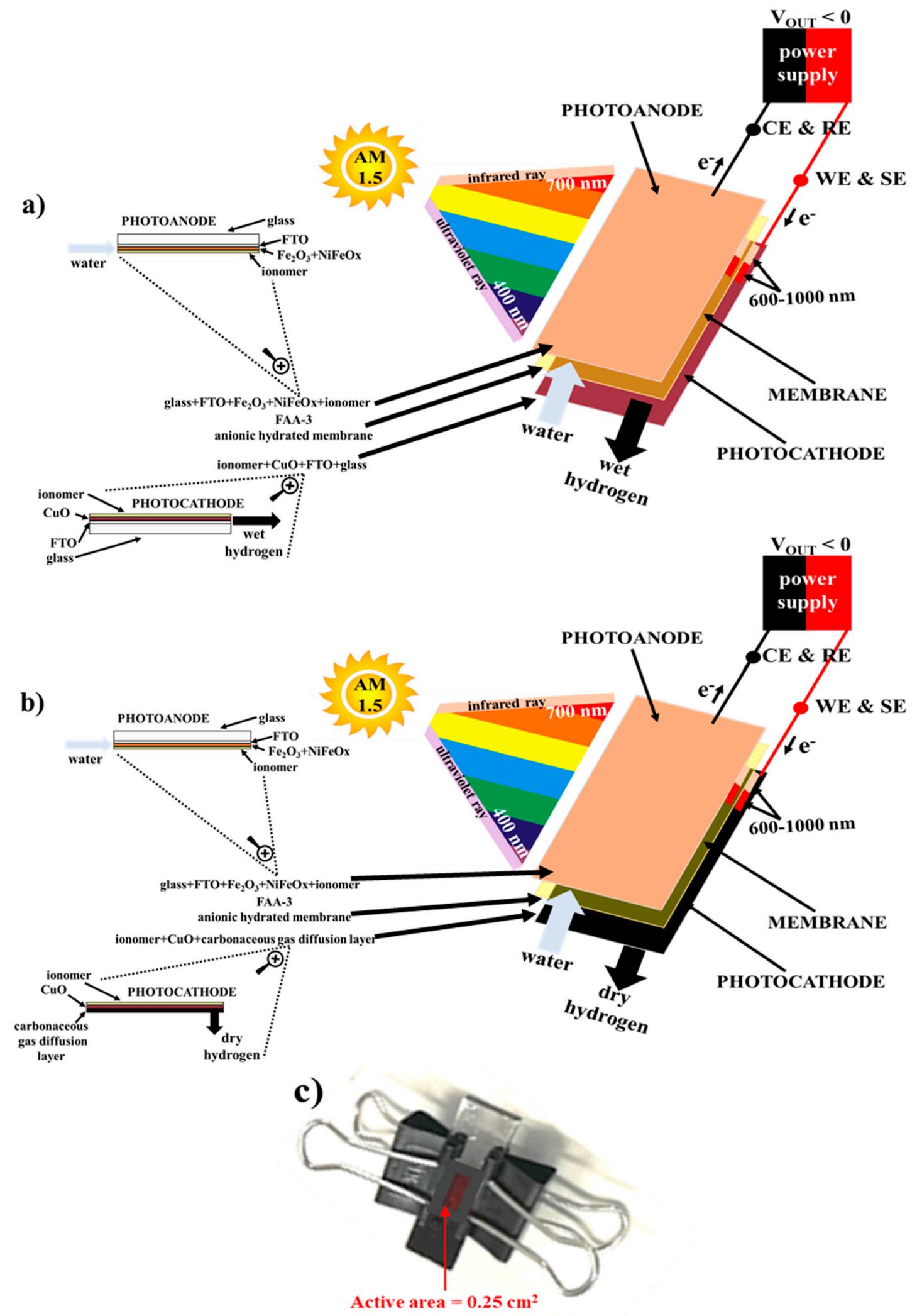

Figure 3. Schematic sketch of the photoelectrochemical cell (PEC) with conductive glass (a), carbonaceous gas diffusion layer (b) as cathode substrate; (c) photograph of PEC with carbonaceous gas diffusion backing layer as cathode substrate. 


\subsubsection{FTO Backing-Based Cell}

The photoanode consisted of a sequence of various layers made of glass, $\mathrm{FTO}, \mathrm{Fe}_{2} \mathrm{O}_{3}, \mathrm{NiFeO}_{\mathrm{X}}$ and ionomer. The electrolyte was based on an FAA-3 transparent anionic solid polymer hydrated membrane. The photocathode consisted of a sequence of the following layers starting from the membrane i.e., ionomer, $\mathrm{CuO}, \mathrm{FTO}$ and glass.

\subsubsection{Hydrophobic Carbonaceous Backing-Based Cell}

The photoanode and the electrolyte were exactly the same of the FTO-based cell. The photocathode consisted of a sequence of the following layers starting from the membrane i.e., ionomer, $\mathrm{CuO}$, Sigracet ${ }^{\circledR}$ or Sigracet ${ }^{\circledR}+7 \%$ FEP addition or Sigracet ${ }^{\circledR}+15 \%$ FEP addition.

The cell is kept under compression by two clamps. This approach reflects just a preliminary investigation of the cell based on the hydrophobic backing where membrane hydration allows to provide the water needed for the reaction and the ionomer interlayers between the electrodes and the membrane allow the gases escape from the cell. The gas impermeable membrane is hydrophilic and when is properly hydrated it also acts as a water reservoir for the cell.

Figure 4 shows the XRD analysis of the $\mathrm{CuO}$ photocathode, the cathodic substrate and $\mathrm{CuO}$ semiconductor deposited over the substrates. Figure 4a shows the XRD pattern of the synthesised $\mathrm{CuO}$ photocathode, confirming the presence of the $\mathrm{CuO}$ monoclinic $\mathrm{C} 2 / \mathrm{c}$ space group structure, with a calculated average crystallite size from the Debye-Scherrer equation, of about $5 \mathrm{~nm}$. Then, the XRD graphs of bare Sigracet ${ }^{\circledR}$ GDL (Figure 4 b) and FTO (Figure 4c) are shown confirms the typical structures of these substrates. Figure $4 \mathrm{~d}$ shows the XRD pattern of the $\mathrm{CuO}$ semiconductor spray deposited on the FTO (Figure 3a). Both peaks of $\mathrm{CuO}$ and FTO are present, with an average crystallite size of $38 \mathrm{~nm}$ for $\mathrm{CuO}$. This crystallite growth is due to the thermal annealing at $350^{\circ} \mathrm{C}$ after the deposition. Also, in the case of $\mathrm{CuO}$ deposition (spray coating) onto Sigracet $35 \mathrm{BC}{ }^{\circledR}$, the typical peaks of $\mathrm{CuO}$ and graphite, for carbonaceous substrate, with an average crystallite size of $20 \mathrm{~nm}$, are observed (Figure 4e,f).

Figures S2 and S3 in the Supplementary Information show the XRD analysis of the anodic $\mathrm{Fe}_{2} \mathrm{O}_{3}$ semiconductor over the FTO glass with and without surface promoter. The analysis confirmed the presence of $\mathrm{Fe}_{2} \mathrm{O}_{3}$ and FTO, Figure $\mathrm{S} 2$, and of $\mathrm{NiO}$ and $\mathrm{NiFe}_{2} \mathrm{O}_{4}$ crystallographic phases in Figure S3. Both $\mathrm{NiO}$ and $\mathrm{NiFe}_{2} \mathrm{O}_{4}$ are good electrocatalysts for oxygen evolution in alkaline environment [79]. The average crystallite size for $\mathrm{Fe}_{2} \mathrm{O}_{3}$ was about $30 \mathrm{~nm}$. In Figure $\mathrm{S} 4$ presents a photograph comparing the transparent anionic FAA-3 membrane in dry (Figure S4a) and wet (Figure S4b) conditions. The wet membrane is clearly more warp and more yellowish with respect the dry one. However, it is sufficiently transparent to wavelengths higher than $600 \mathrm{~nm}$ [7] not absorbed by $\mathrm{Fe}_{2} \mathrm{O}_{3}$ allowing the bottom $\mathrm{CuO}$ cathodic semiconductor to absorb most of higher wavelengths solar spectrum.

The morphological characteristics of the backing layer-based $\mathrm{CuO}$ photocathode are shown in Figure 5a,b. Three different layers are clearly distinguishable in Figure 5a from the inner to the outer parts: carbon fibers-based macroporous diffusion layer (hydrophobic layer), microporous carbon black layer (MPL) and $\mathrm{CuO}$ semiconductor layer (hydrophilic layer). From the other side (back side), the carbon fibers of the macroporous diffusion layer and the FEP deposits are clearly visible. 

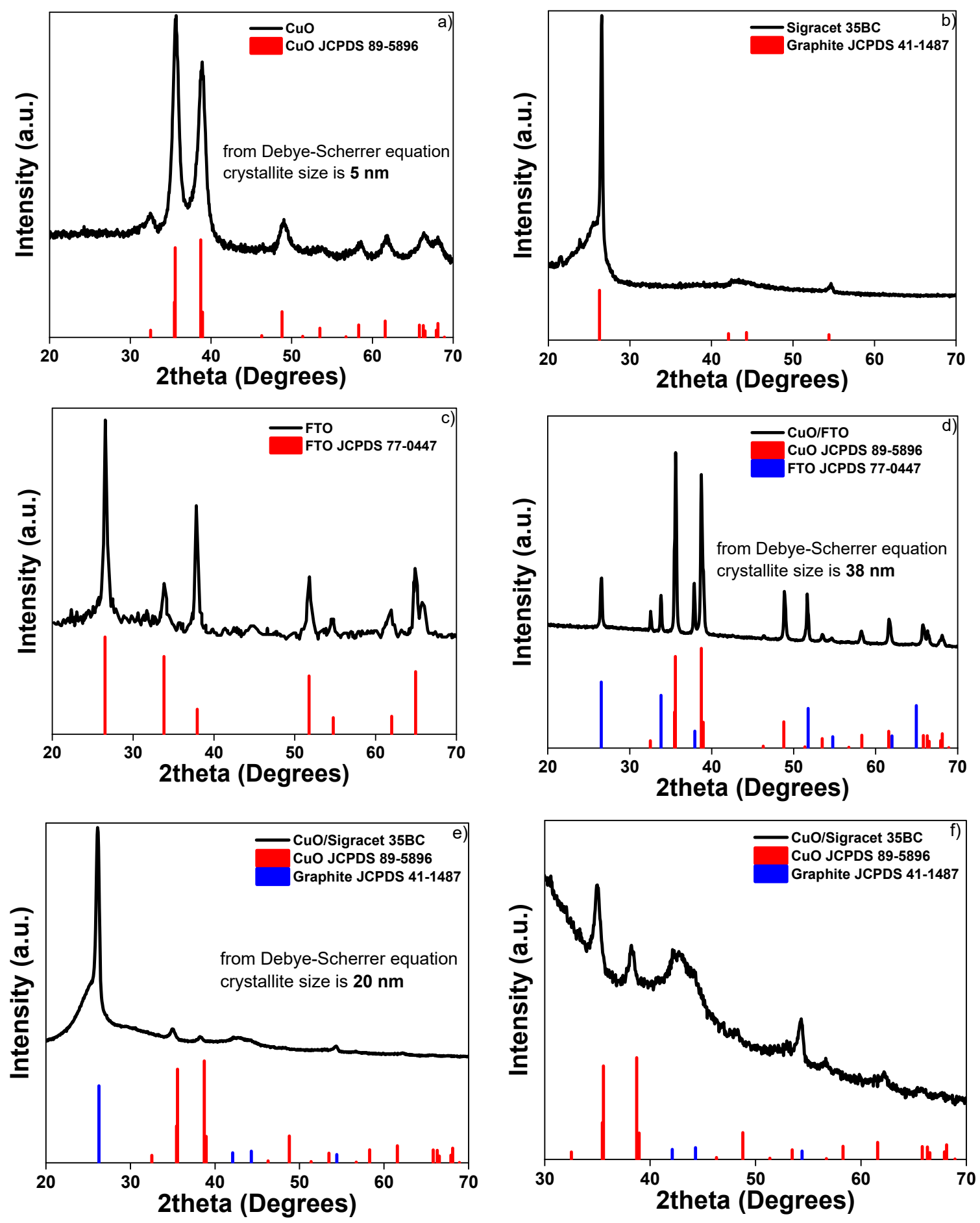

Figure 4. XRD patterns for synthesised photocathode $\mathrm{CuO}(\mathbf{a})$, Sigracet $35 \mathrm{BC}{ }^{\circledR}$ gas diffusion layer (b) FTO on glass (c), $\mathrm{CuO}$ deposited on FTO glass (d), $\mathrm{CuO}$ deposited on Sigracet $35 \mathrm{BC}{ }^{\circledR}$ gas diffusion layer $(\mathbf{e}, \mathbf{f})$ and relative JCPDS cards. 

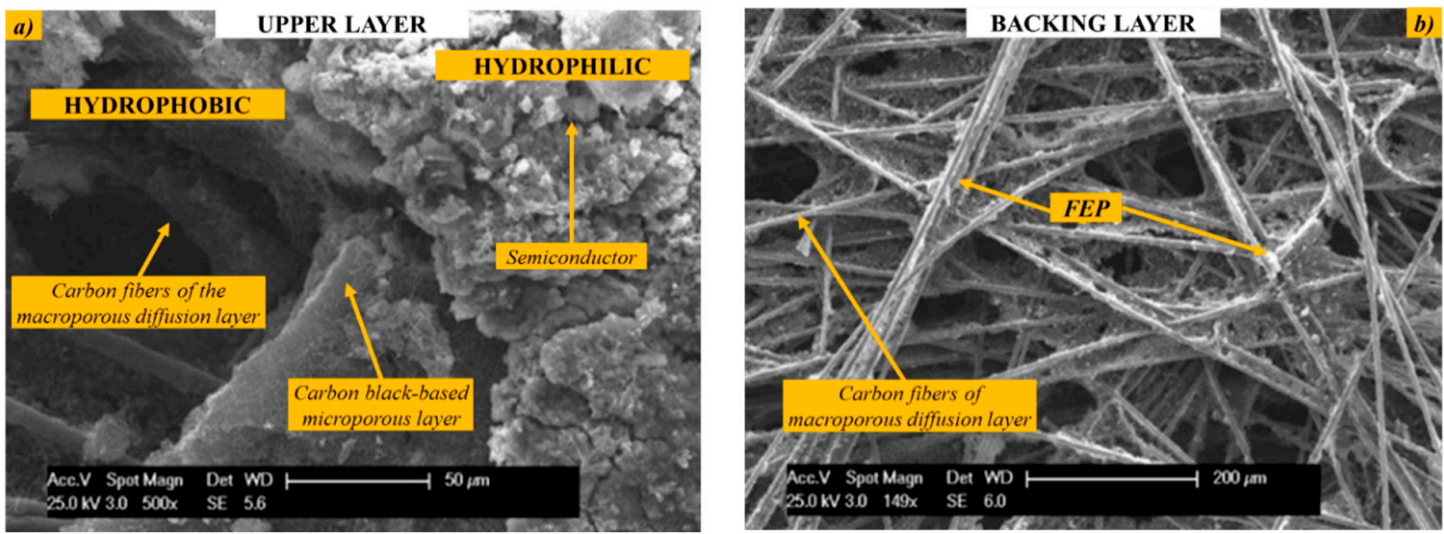

Figure 5. SEM images of the $\mathrm{CuO}$ semiconductor on a Sigracet $35 \mathrm{BC}{ }^{\circledR}$ gas diffusion layer containing $7 \%$ FEP: upper layer (a), backing layer (b).

\subsection{PEC Electrochemical Characterisation}

The complete photoelectrolysis cells were investigated in terms of photoresponse as a function of the cell voltage. The working and sense terminals of the potentiostat-galvanostat were connected to the photocathode and the counter and reference terminals to the photoanode. Both polarisation and photocurrent curves are plotted according to the conventional photodiode representation mode. Accordingly, the light-induced spontaneous photovoltage is assumed as positive and the applied voltage bias is assumed as negative; the photodiode inverse current is negative, and the direct current is positive.

Figure 6a shows the polarisation curves under dark and illumination conditions (AM 1.5) for the complete photoelectrolysis tandem cells based on FTO and various porous hydrophobic carbonaceous backing layers as substrates for the photocathode. Figure $6 \mathrm{~b}$ shows the photocurrent $\left(\mathrm{I}_{\text {light }}-\mathrm{I}_{\text {dark }}\right)$ density variation as a function of the cell potential.
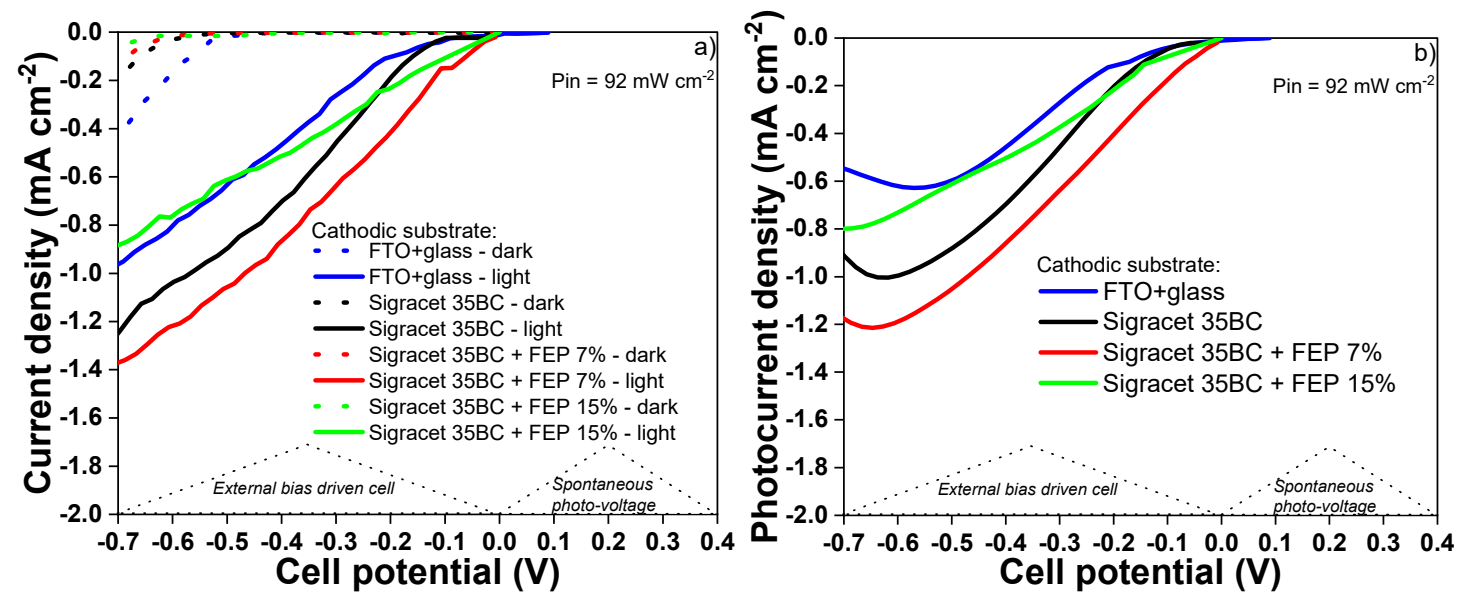

Figure 6. Polarisation curves of the PEC cell (glass $+\mathrm{FTO}+\mathrm{Fe}_{2} \mathrm{O}_{3}+\mathrm{NiFeO}+$ ionomer/FAA-3/ionomer $+\mathrm{CuO}+$ cathodic substrate), for various cathodic substrates, between -0.7 and $0.4 \mathrm{~V}$ (a), photocurrent density vs cell potential between -0.7 and $0.4 \mathrm{~V}(\mathbf{b})$; in the photodiode representation mode an applied bias corresponds to a negative cell potential.

All cells showed a small spontaneous photovoltage of a few hundred $\mathrm{mV}$. However, only upon application of an external voltage bias, a relevant current density was recorded. Under dark conditions, for all samples, the recorded current density, dashed lines in Figure 6a, was lower, as absolute value, than $50 \mu \mathrm{A} \mathrm{cm}^{-2}$ for an applied voltage lower than $0.4 \mathrm{~V}$ (i.e., at cell potentials more positive than $-0.4 \mathrm{~V}$ bias in the polarisation plot). In the case of the FTO substrate, the dark current became $-400 \mu \mathrm{A} \mathrm{cm}{ }^{-2}$ 
at $-0.7 \mathrm{~V}$ bias. For all Sigracet ${ }^{\circledR}$ substrates (bare sample and samples containing $7 \mathrm{wt} \%$ and $15 \mathrm{wt} \%$ of FEP), the dark current was, as absolute value, lower than $200 \mu \mathrm{A} \mathrm{cm}^{-2}$ at $-0.7 \mathrm{~V}$ bias. It was observed that the dark current decreased as the FEP content increased.

Under illumination, the current density increases progressively with the voltage bias. The best current density value was registered in the case of Sigracet ${ }^{\circledR}+$ FEP $7 \mathrm{wt} \%$ This was about $-1.3 \mathrm{~mA} \mathrm{~cm}{ }^{-2}$ at $-0.6 \mathrm{~V}$ bias. The photocurrent $\left(\mathrm{I}_{\text {light }}-\mathrm{I}_{\text {dark }}\right)$ trend as a function of cell potential in Figure $6 \mathrm{~b}$ shows the occurrence of a maximum photocurrent at a cell potential bias of about $-0.6 \mathrm{~V}$. The increase of dark current when a high voltage bias is applied probably interferes with the photoconversion process. This phenomenon may be due to some degradation process at high-applied potentials e.g., a possible reduction of $\mathrm{CuO}$ to metallic copper. The applied bias expands the potential differences among the positive electrode $\mathrm{Fe}_{2} \mathrm{O}_{3}$ and the negative electrode $\mathrm{CuO}$. This should be avoided by keeping the voltage bias within a useful range where the dark current is substantially absent. It is evident that in the case of Sigracet ${ }^{\circledR}+$ FEP 7\% the level of photocurrent was the highest among the various samples throughout the entire range of interest.

In terms of throughput efficiency, the cell based on the optimised gas diffusion backing layer shows a performance that is twice that of the conventional substrate based-cell.

The performance characteristics of a photoelectrolysis cell is assessed in terms of enthalpy and voltage efficiency [7].

Enthalpy efficiency:

$$
\eta_{\text {enthalpy }}=I_{p}\left(\Delta H^{0} / n F-\left|E_{\text {bias }}\right|\right) / P_{\text {in }}=I_{p}\left(E_{\text {tn }}-\left|E_{\text {bias }}\right|\right) / P_{\text {in }}
$$

Throughput efficiency:

$$
\begin{gathered}
\eta_{\text {throughput }}=I_{p}\left(\Delta \mathrm{H}^{0} / n F\right) /\left(P_{\text {in }}+\left|I_{p} E_{\text {bias }}\right|\right)=I_{p} E_{\text {tn }} /\left(P_{\text {in }}+\left|I_{p} E_{\text {bias }}\right|\right) \\
\eta_{\text {enthalpy }} \%=100 \eta_{\text {enthalpy }} ; \eta_{\text {throughput }} \%=100 \eta_{\text {throughput }}
\end{gathered}
$$

where the thermoneutral potential $\mathrm{E}_{\mathrm{tn}}=1.48 \mathrm{~V}$, the voltage bias $\mathrm{E}_{\mathrm{bias}} \equiv \mathrm{V}$ is the applied voltage, the illumination power $P_{\text {in }} \equiv 92 \mathrm{~mW} \mathrm{~cm}^{-2}$ (as measured by a calibrated photovoltaic cell), the photocurrent density $I_{p}=I_{\text {light }}-I_{\text {dark }} \equiv \mathrm{mA} \mathrm{cm}^{-2}$ is the difference between the current density under illumination and the current density in the dark. $\Delta \mathrm{H}^{\circ}$ is the standard enthalpy reaction i.e., the overall energy content of the products $\Delta \mathrm{H}^{\circ}=\Delta \mathrm{G}^{\circ}+\mathrm{T} \Delta \mathrm{S}^{\circ} ; \mathrm{n}$ is the number of equivalents exchanged in the water splitting reaction i.e., 2 electrons exchanged per water molecule; F is the Faraday constant, $96485 \mathrm{C} \mathrm{mol}^{-1}$.

Assuming a Faradaic efficiency of $100 \%$, the enthalpy efficiency corresponds to ratio between the hydrogen production rate multiplied by the standard enthalpy of combustion (high heating value, $\mathrm{HHV}$ ) subtracted by the energy input as voltage bias and the solar power input.

The throughput efficiency corresponds to the ratio between the cell power output (HHV of the produced hydrogen per unit of time) and the overall power input (solar + electric) supplied by any external source.

Thus, according to the results shown in Figure $6 \mathrm{a}, \mathrm{b}$, the cell based on a conventional FTO-glass substrate at the cathode shows much lower performance compared to the optimised cell based on the carbonaceous gas-diffusion backing layer. The cell based on the optimised gas diffusion backing layer shows a maximum photocurrent density of $1.2 \mathrm{~mA} \mathrm{~cm}^{-2}$ that is twice that of the conventional substrate based-cell. This is essentially due to an enhancement of hydrogen diffusivity by effective separation from water at the cathode and an increase of the semiconductor activity because of the large interface with the backing carbonaceous backing layer.

To highlight the efficiency characteristics as a function of the cell potential, the enthalpy efficiency (Figure 7a) and throughput efficiency (Figure 7b) are plotted as a function of the applied bias. The curves were calculated from the previous polarisation points applying Equations (5)-(7). 

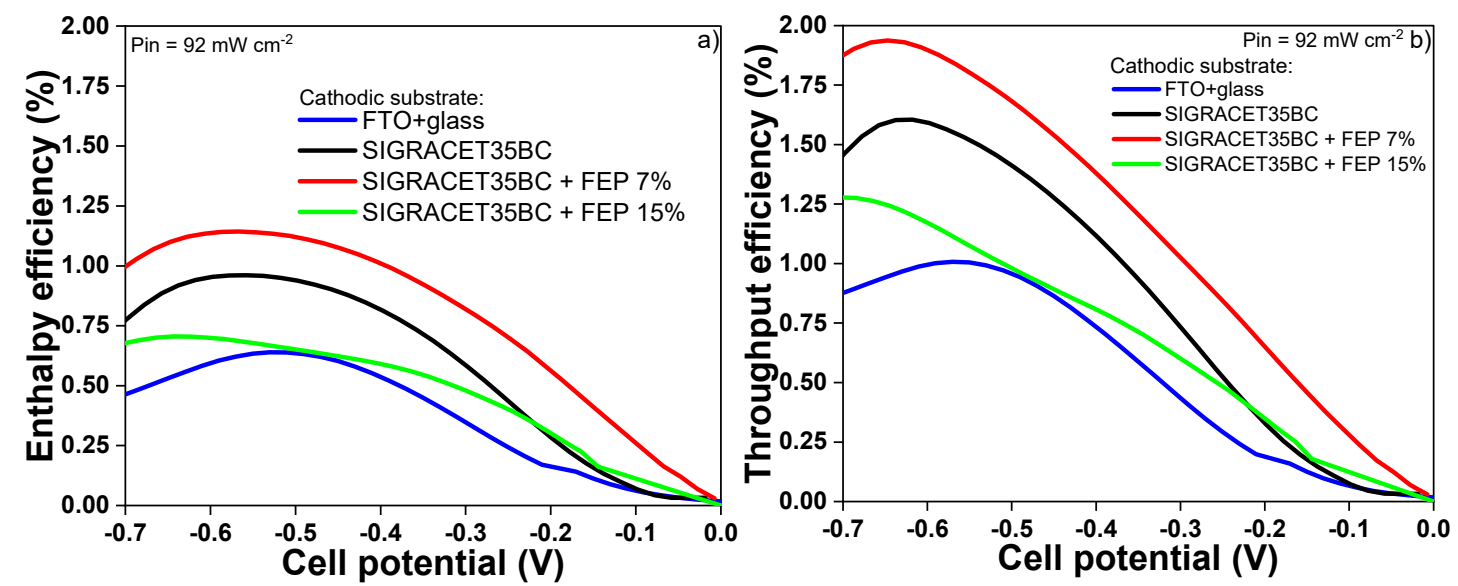

Figure 7. PEC enthalpy efficiency (a) and throughput efficiency (b) as a function of cell potential for various photocathode substrates.

Figure 7 shows that the photoelectrolysis cells based on the porous hydrophobic carbonaceous backing layer are performing better than the cell using an FTO substrate for the photocathode.

The maximum enthalpy efficiency was recorded between -0.5 and $-0.6 \mathrm{~V}$ voltage bias. The best value was recorded for the cell based on the Sigracet ${ }^{\circledR}+7 \mathrm{wt} \%$ FEP substrate-based cell i.e., $1.14 \%$ at $-0.56 \mathrm{~V}$ bias. For the same cell, a value of $1.93 \%$ was achieved for the throughput efficiency at $-0.65 \mathrm{~V}$, assuming $100 \%$ Faradaic efficiency for hydrogen production. For other substrates, the enthalpic efficiency was lower than $1 \%$, while the throughput efficiency was about $1.5 \%$ in the best case. The cell based on the FTO substrate at the cathode showed enthalpy and throughput efficiencies of $0.65 \%$ and $1 \%$ respectively. Thus, double throughput efficiency was achieved by using an appropriate GDL substrate at the cathode.

It should be pointed out that these efficiency characteristics are achieved with a photoelectrochemical device based on non-CRM materials at practical bias voltages i.e., $-0.6 \mathrm{~V}$, whereas most of efficiency values reported in the literature are obtained at the reversible potential i.e., at $-1.23 \mathrm{~V}$ bias often using CRMs.

To better understand the causes that have produced a much higher cell efficiency in the presence of the porous hydrophobic Sigracet $35 \mathrm{BC}{ }^{\circledR}$ modified with $7 \%$ of FEP as a photocathode GDL substrate, electrochemical impedance spectroscopy measurements, in dark and light conditions, were carried out.

For all samples, the complete spectra, at $-0.6 \mathrm{~V}$ voltage bias, are shown in Figure $8 \mathrm{a}$, while Figure $8 \mathrm{~b}$ shows a zoom of the previous spectra at high frequencies. A significant difference is noted in Figure $8 \mathrm{~b}$ for the series resistance values, $\mathrm{R}_{\mathrm{S}}$ ( $\mathrm{x}$-axis intercept at high frequencies), between the carbonaceous substrates and FTO, independently from dark and light conditions. For the FTO sample, the series resistance was about $37 \Omega \mathrm{cm}^{2}$, whereas, for the Sigracet ${ }^{\circledR}$ samples about $20 \Omega \mathrm{cm}^{2}$ (almost one-half). From Figure 8a, it was evident a rectifying behaviour (low capacitance or high imaginary Z" values) for all the samples under dark conditions. Interestingly, the rectifying behaviour increases passing from the FTO to the carbonaceous substrate and for the latter it further increases with the FEP content.

Conversely, under illumination, two semicircles can be distinguished, possibly corresponding to the hydrogen and oxygen evolution reactions. The FTO-substrate-based cell shows lower charge transfer resistance under illumination than the carbonaceous substrates but the gap with the GDL containing 7\% FEP becomes very small at the lowest frequency. The increasing trend for the FTO-based cell at low frequencies possibly indicates that in the diffusion region (mass transfer region) at very low frequencies (unfortunately not covered by the present analysis due to relevant noise occurrence), the cell impedance in the presence of the carbonaceous substrates may became smaller than the FTO-based cell. This would indicate that there might be a specific advantage using such porous substrates in favouring the gas escape through the gas diffusion backing layer. 

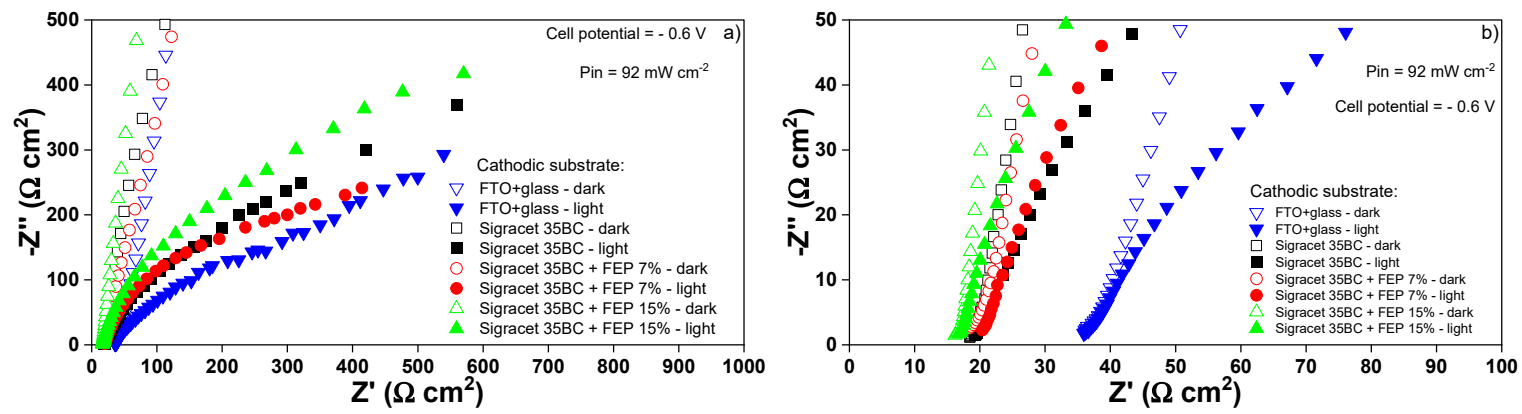

Figure 8. Electrochemical Impedance Spectroscopy of the PEC cell (glass $+\mathrm{FTO}+\mathrm{Fe}_{2} \mathrm{O}_{3}+\mathrm{NiFeOX}$ + ionomer/FAA-3/ionomer $+\mathrm{CuO}+$ cathodic substrate), for various photocathode substrates under illumination with an applied cell bias of $-0.6 \mathrm{~V}(\mathbf{a})$; magnification of these spectra at high frequencies $(\mathbf{b})$.

A chronoamperometric test was carried out for the best performing PEC based on the Sigracet ${ }^{\circledR}+$ $7 \mathrm{wt} \%$ FEP GDL with proper cell hydration (Figure 9a). The cell was polarised at $-0.6 \mathrm{~V}$ and the relative current density was recorded by varying the illumination conditions. The steady-state current density in the dark was less than $20 \mu \mathrm{A} \mathrm{cm}^{-2}$ at $-0.6 \mathrm{~V}$, while it was about $1.1 \mathrm{~mA} \mathrm{~cm}^{-2}$ under illumination. The very low dark current suggests no side reactions are occurring at relevant extent. An appropriate stability was observed with a constant enthalpy efficiency of $1.1 \%$. Passing from dark to light and vice versa, the current variation shows a slight mismatching with light conditions due to the sampling range. In general, the photoresponse of this type of photoelectrolysis cell appears relatively slow compared to a photovoltaic system. The same experiment was carried out for the FTO cathode substrate-based cell. The photoresponse was significantly lower and a dark current was present probably indicating some current leakage in this device (Figure $9 b$ ).
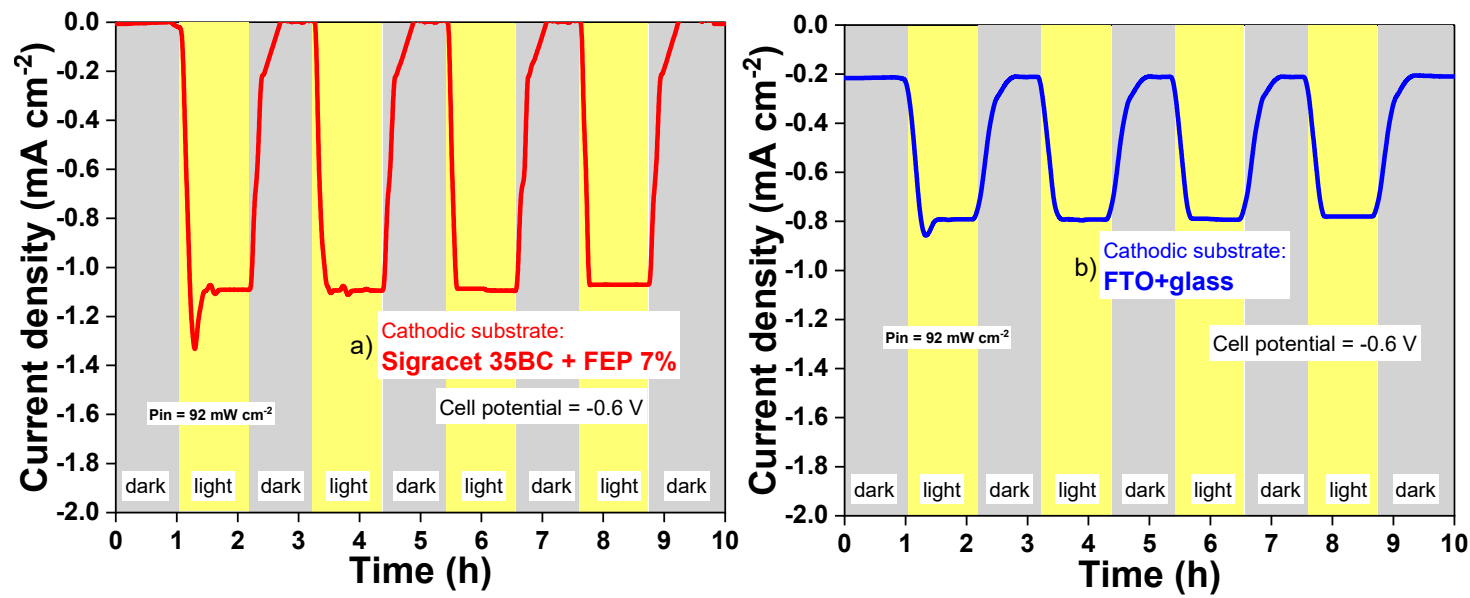

Figure 9. Potentiostatic durability test (applied cell bias of $-0.6 \mathrm{~V}$ ) of the PEC cells based on the hydrophobic backing layer (a) and FTO (b) cathode substrates contained into a quartz holder filled with water for cell hydration.

In Figure S5 (Supplementary Information), we have analysed by mass spectrometry the output stream at the cathode with reference to $\mathrm{H}_{2}$ and $\mathrm{CO}$ signals. The ionic current related to hydrogen increases during illumination at $-0.6 \mathrm{~V}$ showing large oscillations whereas the $\mathrm{CO}$ signal is not affected.

To further validate the possibility of producing almost dry hydrogen in the output stream, we have placed a small piece of filter paper below the hydrophobic layer in a durability test (Figure S6a,b). No traces of humidity have been detected (Figure S6c). In the supplementary information, we also show that under relevant hydrostatic pressure, with the water contained in an open burette placed over the hydrophobic substrate, this does not permeate through the hydrophobic layer (Figure S7a-c). 
After, the durability test, the cell was dismantled and analysed. This analysis was made difficult by the fact that the electrodes were strongly attached to the membrane. The morphological characteristics of the photocathode consisting of a CuO semiconductor layer deposited on a Sigracet ${ }^{\circledR} 35 \mathrm{BC}$ gas diffusion layer made of hydrophobised carbon nanoparticles and carbon fibers, after the time-test, are shown in Figure 10a-c. A portion of the $\mathrm{CuO}$ overlayer was scraped to show the carbon layer below. Thus, Figure 10a shows a region where both the upper hydrophilic $\mathrm{CuO}$ semiconductor layer and the backing hydrophobic carbon layer are visible. Either a corrugated or a smooth area compose the hydrophilic layer. The smooth area reflects a large concentration of ionomer. The $\mathrm{CuO}$ semiconductor nanoparticles are clearly visible in Figure 10b. The $\mathrm{CuO}$ layer has a porous structure composed of nanospheres allowing proper electron percolation and hydrogen diffusion towards the backing layer. The underlying hydrophobic layer is composed by microporous carbon nanoparticles and polytetrafluoroethylene (PTFE) allowing fast diffusion of the hydrogen produced during the water reduction process towards the outer electrode face. In principle, also water may permeate through such porous carbon structure, but the highly hydrophobic properties allow only the gas diffusion. The hydrophobic properties are further enhanced by the addition of FEP. As shown in Figure 10c, the FEP polymer is also integrated within the carbon fibers on the backing layer of the carbonaceous substrate, thus creating a hydrophobic barrier. The X-ray diffraction analysis of the photocathode after the short durability test at $-0.6 \mathrm{~V}$ (Figure $10 \mathrm{~d}$ ) does not show any relevant modification compared to the original characteristics. It is not excluded that modification of the $\mathrm{CuO}$ surface under cathodic conditions may occur especially after a long durability test. This needs a specific surface analysis, and it will be investigated in a successive work.
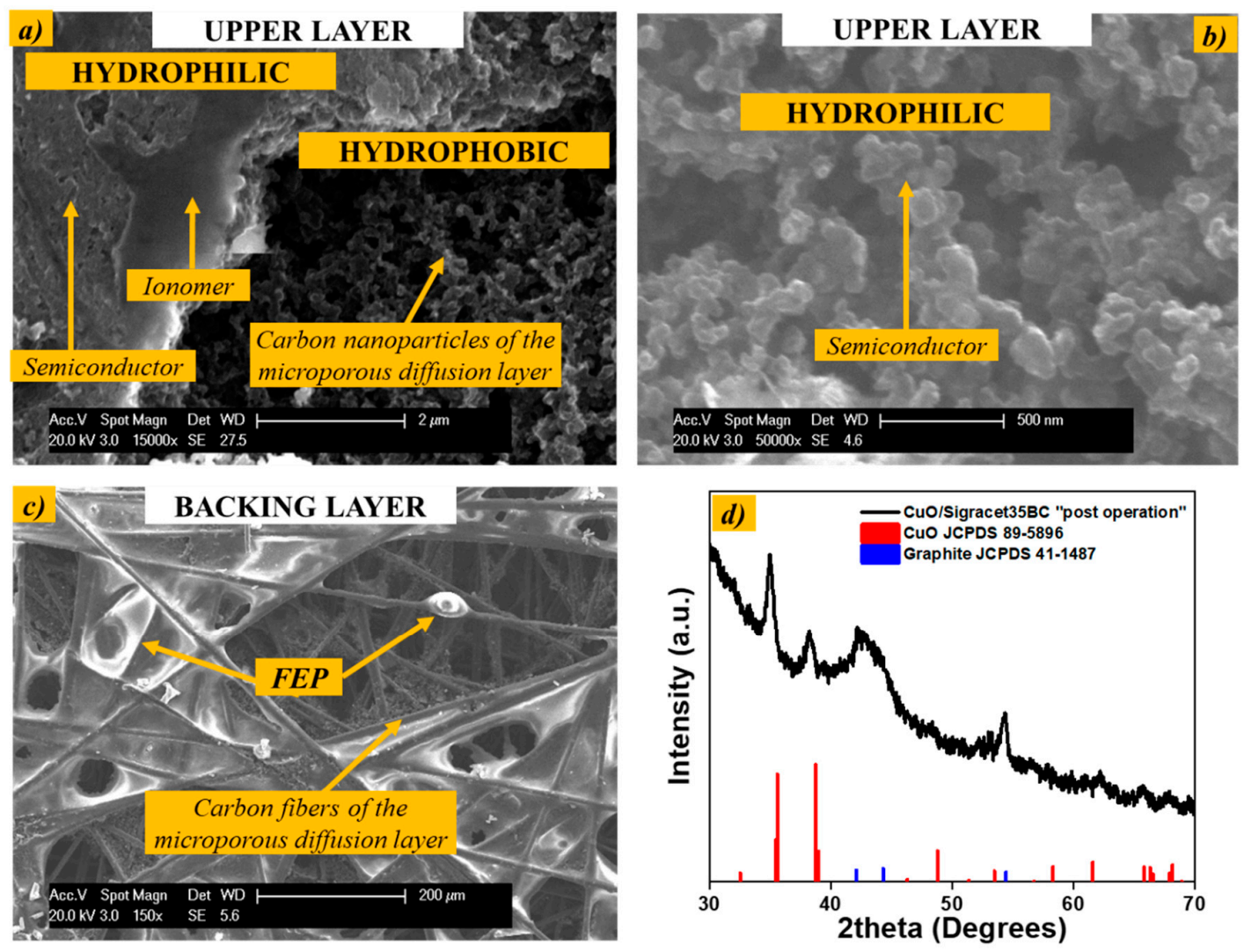

Figure 10. Post operation SEM images of the $\mathrm{CuO}$ semiconductor deposited on a Sigracet $35 \mathrm{BC}{ }^{\circledR}$ gas diffusion layer containing $7 \mathrm{wt} \%$ FEP: upper layer (a,b), backing layer (c). Post-operation X-ray diffraction analysis of the photocathode $(\mathbf{d})$. 
The photoanode was not modified by the durability test as it results from the observation of its surface by scanning electron microscopy before and after the potentiostatic test (Supplementary information Figure S8). The developed tandem photoelectrolysis cells, based on (i) low cost and non CRM materials, (ii) a transparent anionic membrane separator and iii) the use of a gas diffusion layer at the cathode, to allow obtaining dry hydrogen in the output stream, appear to provide a practical and promising solution to enhance performance, stability and reliability of solar driven water splitting devices. By utilisation of the Sigracet $35 \mathrm{BC}{ }^{\circledR}$, further waterproofed with $7 \%$ of FEP, a significant increase of enthalpic and throughput efficiency was achieved in comparison with the FTO photocathode substrate in line with the best results reported in the literature for non-CRM semiconductors $[7,26,28]$.

\section{Materials and Methods}

\subsection{Anodic Substrates}

Fluorine-doped tin oxide (FTO) glass, provided by Solaronix (Aubonne, Switzerland) with code TCO22-7, was used as photoanode substrate (geometric area $1 \mathrm{~cm}^{2}$ ). This substrate had a thickness of $2.2 \mathrm{~mm}$ and a resistivity of $7 \Omega \mathrm{sq}^{-1}$.

\subsection{Synthesis of Photoanodes}

In a glass reactor, containing an aqueous solution of $0.15 \mathrm{M} \mathrm{FeCl}_{3}$ and $1 \mathrm{M} \mathrm{NaNO}_{3}$, several FTO glass pieces, each with a geometric area of $1 \mathrm{~cm}^{2}$, vertically aligned and covered with a black adhesive tape to obtain an active area of $0.25 \mathrm{~cm}^{2}$, were dived. The chemical bath deposition of FeOOH over FTO was obtained by heating the reactor at $100{ }^{\circ} \mathrm{C}$ for $6 \mathrm{~h}$. Then, the formed electrodes were washed with water and dried at room temperature. Thus, the electrodes were thermally annealed at $650{ }^{\circ} \mathrm{C}$ for $1 \mathrm{~h}$ in air in order to achieve a $\alpha-\mathrm{Fe}_{2} \mathrm{O}_{3} /$ FTO structure.

These $\alpha-\mathrm{Fe}_{2} \mathrm{O}_{3} / \mathrm{FTO}$ electrodes were put in an oven at $750{ }^{\circ} \mathrm{C}$ for $15 \mathrm{~min}$ to get $\mathrm{Sn}$ doping [7]. The electrodes were cooled down to room temperature. To obtain an additional doping with $\mathrm{P}$, the Sn-modified electrodes were dived in a $0.1 \mathrm{~mol} \mathrm{~L}^{-1}$ aqueous solution of $\mathrm{NH}_{4} \mathrm{NaHPO}_{4}$ (Sigma-Aldrich $99 \%$, St. Louis, MO, USA). The electrodes were kept in the solution for $1 \mathrm{~min}$ to achieve an immersion casting procedure and withdrawn with a rate of $450 \mathrm{~mm} / \mathrm{min}$. Afterwards, the samples were dried at $100{ }^{\circ} \mathrm{C}$ for $30 \mathrm{~min}$ and thereafter they were annealed at $450{ }^{\circ} \mathrm{C}$ for $30 \mathrm{~min}$ in air [80].

The $\mathrm{NiFeO}_{\mathrm{X}}$ promoter was prepared according to the "oxalate method" [81]. Ni and Fe nitrates were dissolved in distilled water and mixed with a solution of oxalic acid neutralised at $\mathrm{pH} 6.5$ with $\mathrm{NaOH}$. The chelating agent and the metal precursors were in a molar ratio of 10. A metal complex was formed, and it was treated with hydrogen peroxide at $80^{\circ} \mathrm{C}$ to obtain a precipitate. After filtering, washing and drying at $100{ }^{\circ} \mathrm{C}$ for $24 \mathrm{~h}$, the obtained powder was calcined at $350{ }^{\circ} \mathrm{C}$ for $120 \mathrm{~min}$ to form a NiFeOx phase. $12 \mu \mathrm{g} \mathrm{cm}{ }^{-2}$ of $\mathrm{NiFeO}_{X}$ was deposited onto the doped $\mathrm{Fe}_{2} \mathrm{O}_{3}$ surface by doctor blade technique using a proper ink. The final photoanodes were subjected to a heat treatment at $450{ }^{\circ} \mathrm{C}$ for $1 \mathrm{~h}$.

\subsection{Photocathode Substrates}

Three cathodic substrates were investigated: FTO glass, mentioned in Section 3.1; a porous carbon paper named Spectracarb ${ }^{\circledR}$ 2050A-1550 (Engineered Fibers Technology, Shelton, CT, USA), and a non-woven carbon paper carbon paper containing a microporous layer that was made of $5 \mathrm{wt} \%$ polytetrafluoroethylene (PTFE) and carbon black named Sigracet $35 \mathrm{BC}^{\circledR}$ (SGL carbon, Wiesbaden, Germany).

The Spectracarb ${ }^{\circledR} 2050 \mathrm{~A}-1550$ gas diffusion layer is a heavy duty porous graphitised carbon sheet with low compressibility and with general utility for a range of polymer electrolyte membrane (PEM) fuel cell applications. The most important properties of this layer are a high electrical conductivity, good mechanical strength and durability, and good gas/air permeability. The thickness was of $381 \mu \mathrm{m}$, with a porosity of $78 \%$. 
Sigracet $35 B C^{\circledR}$ is a non-woven carbon paper with a microporous layer, on one side, containing $5 \mathrm{wt} \%$ PTFE. This is a low-cost alternative to conventional woven carbon cloth gas diffusion layers in fuel cell applications. The Sigracet ${ }^{\circledR}$ carbon fiber paper 35 Series combine a high robustness with excellent conductivity and mass transport properties. The thickness was of $325 \mu \mathrm{m}$ with a porosity of $80 \%$.

Both Spectracarb ${ }^{\circledR}$ and Sigracet $35 \mathrm{BC}{ }^{\circledR}$ are hydrophobic. However, for both substrates a further hydrophobisation treatment was carried out to understand how this process could influence the electrical and wettability characteristics.

The procedure for the carbonaceous backing layer waterproofing consisted of the following steps:

- Cutting $1 \mathrm{~cm}^{2}$ of the sample and weighting.

- Preparation of a solution of FEP, fluorinated ethylene propylene, (Zeus, Orangeburg, SC, USA) $55 \%-\mathrm{H}_{2} \mathrm{O} 1: 1$ in volume.

- Diving of the sample, one layer (for Sigracet ${ }^{\circledR}$ the side with MPL) or both layers (full), for $60 \mathrm{~s}$ or $120 \mathrm{~s}$ or $300 \mathrm{~s}$.

- Drying of the sample between two filter papers applying a light pressure.

- Heat-treatment in a furnace with a ramp up to $70^{\circ} \mathrm{C}\left(5^{\circ} \mathrm{C} / \mathrm{min}\right)$, dwell time of $15 \mathrm{~min}$, ramp up to $375^{\circ} \mathrm{C}\left(5^{\circ} \mathrm{C} / \mathrm{min}\right)$, dwell time $15 \mathrm{~min}$, ramp down to $25^{\circ} \mathrm{C}$.

The samples as received and subjected to waterproofing procedure were weighted before and after this treatment to evaluate the FEP uptake.

FEP uptake is defined as follows:

$$
\mathrm{FEP}_{\text {uptake }}=\left(\left(\mathrm{W}_{\text {after }}-\mathrm{W}_{\text {before }}\right) /\left(\mathrm{W}_{\text {before }}\right)\right) \times 100
$$

where $\mathrm{W}_{\text {after }}$ is the weight in $\mathrm{mg}$ measured after the waterproofing procedure; $\mathrm{W}_{\text {before }}$ the weight in mg measured before waterproofing.

All the samples were investigated in terms of electrical conductivity and contact angle measurements, see paragraphs 3.6 and 3.7. For testing in a complete cell configuration, only FTO and Sigracet $35 \mathrm{BC}^{\circledR}$, as received and with two hydrophobisation grades (7 and $15 \mathrm{wt} \% \mathrm{FEP}$ ) were investigated, due to proper trade-off between waterproof properties and electrical conductivity.

\subsection{Synthesis of Photocathodes}

$\mathrm{CuO}$ powder precursor was prepared according to the "oxalate method" [81]. The powder was annealed at $350{ }^{\circ} \mathrm{C}$ for $2 \mathrm{~h}$ with the formation of $\mathrm{CuO}_{\mathrm{X}}$ nanoparticles. A reduction of the $\mathrm{CuO}$ powder to finely dispersed metallic copper was carried out at $200{ }^{\circ} \mathrm{C}$ in a $10 \% \mathrm{H}_{2}-90 \% \mathrm{~N}_{2}$ atmosphere and the sample was cooled overnight. The metallic $\mathrm{Cu}$ was dispersed in isopropyl alcohol under sonication. Finally, this solution was deposited onto the substrate with a delimited active area of $0.25 \mathrm{~cm}^{2}$, by using a spray technique. The cathodic substrates were either FTO or Sigracet $35 B C^{\circledR}$ or Sigracet $35 \mathrm{BC}^{\circledR}+$ FEP addition. A Cu metal loading of $2.0 \mathrm{mg} \mathrm{cm}^{-2}$ was obtained. Finally, $\mathrm{CuO}$ was formed again by a thermal treatment of the electrodes at $350{ }^{\circ} \mathrm{C}$ in air. The intermediate step of metallic copper formation was necessary to achieve a homogeneous deposition over the substrate and proper adhesion of the semiconductor to the backing layer.

\subsection{Anionic Solid Polymer Transparent Membrane and Ionomer Preparation}

A Fumasep membrane (Fumatech, Bietigheim-Bissingen, Germany), based on a brominated polysulfone backbone with quaternary ammonium side chain groups provided in bromide form, FAA-3-50, with a thickness of $50 \mu \mathrm{m}$, was subjected to ion exchange in $\mathrm{KOH}$ (Sigma-Aldrich, St. Louis, MO, USA) [68]. The used membrane had a sufficiently high conductivity to keep ohmic losses associated with ion transport in the polymer electrolyte separator within $1 \mathrm{mV}$ in the range of recorded photoelectrolysis current densities. The anionic solid polymer transparent membrane was hydrated for $1 \mathrm{~h}$. 
An alcoholic solution of $n$-propanol and ethanol $(1: 1 \mathrm{wt})$ was used to prepare an ionomer dispersion by solubilizing the received solid ionomer powder (FAA-3-shredded film) at room temperature under stirring to have $\sim 5 \mathrm{wt} \%$ dispersion. The ionomer was deposited, by drop casting on the photocathode and photoanode before assembling the electrodes with the membrane to form the PEC [68].

\subsection{Assembly of the PEC}

The assembly of the PEC consisted in making a close contact of the different elements under moderate compression. The photoanode and photocathode were hydrated by water addition over the active area. The hydrated membrane was positioned above the photocathode and above this one the photoanode so as to have the following assembly:

(1) photoanode: glass $+\mathrm{FTO}+\mathrm{Fe}_{2} \mathrm{O}_{3}+\mathrm{NiFeO}_{\mathrm{X}}+$ ionomer

(2) electrolyte: FAA-3 anionic solid polymer transparent hydrated membrane

(3) photocathode: ionomer $+\mathrm{CuO}+\left(\mathrm{FTO}+\right.$ glass or $\left(\right.$ Sigracet $\left.^{\circledR}\right)$ or $\left(\right.$ Sigracet $^{\circledR}+\mathrm{FEP}$ addition$)$

The glass side of the hematite coated FTO electrode, directly exposed to light irradiation, was covered by a black insulating tape, with a central hole with a well-defined area of $0.25 \mathrm{~cm}^{2}$. Finally, to have a good pressure over the assembling, two clamps at each side of the cell were used.

The PEC was placed in a transparent holder and illuminated from the photoanode by a solar simulator (Oriel Newport, Irvine, CA, USA). Dry nitrogen was fluxed into the holder to avoid oxygen contamination. For durability tests, the cell was immersed in a transparent holder equipped with a quartz window and containing distilled water that was flushed continuously with nitrogen.

\subsection{Physicochemical Characterisation}

An X-pert $3710 \mathrm{X}$-ray diffractometer (Panalytical Italia, Lissone, Italy) equipped with a Cu-K $\alpha$ radiation operating at $40 \mathrm{kV}$ and $20 \mathrm{~mA}$ was used to analyze the crystalline phase of the specimens. The crystallite size was determined from the peaks broadening using the Debye-Scherrer equation.

The morphology of the Sigracet ${ }^{\circledR}$ substrate was studied by scanning electron microscopy (SEM) with a FEI-XL 30 SEM microscope (FEI, Eindhoven, The Netherlands).

The static contact angle measurements, for the different gas diffusion layers subjected to waterproof procedures, were carried out using the OCA-25 model of the DataPhysics Instruments GmbH (Filderstadt, Germany). The sessile drop procedure was adopted employing water as a liquid with a volume drop of $2 \mu \mathrm{L}$ dispensed with a drop rate of $0.5 \mu \mathrm{L} / \mathrm{s}$ on the surface of the films. The drop-shape was analysed by an ellipse fitting method [82]. For both fully dived and one-layer diving samples, the contact angle measurements were carried out on the rear side, opposite to the side where $\mathrm{CuO}$ deposition subsequently occurred.

\subsection{Electrochemical Tests}

The electrochemical apparatus consisted of a Metrohm Autolab potentiostat/galvanostat (Utrecht, The Netherlands) equipped with a Frequency Response Analyzer (FRA). The working and sense electrodes were connected to photocathode, while the counter and reference electrodes to photoanode. An Oriel solar simulator providing an irradiation of about $92 \mathrm{~mW} \mathrm{~cm}^{2}$, as measured by a calibrated photovoltaic cell, was used.

Polarisation measurements $\left(20 \mathrm{mV} \mathrm{s}^{-1}\right)$ under illumination were carried out in a wide potential range starting from the spontaneous open circuit photovoltage (OCP) (spontaneous cell photo-voltage region), passing through the short circuit photocurrent ( $\left.\mathrm{I}_{\mathrm{SC}}\right)$ to $-0.7 \mathrm{~V}$ applied cell voltage (external bias driven cell region). Higher applied potentials were avoided because of a potential cathode degradation. The polarisations curves were carried out first in the dark and thereafter under illumination. These curves are plotted with the sign of photocurrent and potential bias as negative (reverse current and applied bias) as in the case of photodiode mode. In the case of spontaneous photovoltage the sign is positive like in a photodiode. Ac-impedance measurements were carried out 
at $-0.6 \mathrm{~V}$ under single-sine mode by sweeping frequencies from $100 \mathrm{kHz}$ to $10 \mathrm{mHz}$ using $10 \mathrm{mV}$ root mean square (rms) excitation sinusoidal signal.

The trough-plane electrical conductivity was measured by four-wire electrochemical impedance spectroscopy for the bulk of the gas diffusion layers using a Greenlight (Greenlight Innovation, Burnaby, BC, Canada) test fixture. The apparatus consisted of two alumina tubes applying a precise pressure on the two sides of the sample. A gold gauze pressed at a controlled pressure over the sample, on both sides, assured the electric contact.

Electrical conductivity, dimensionally in $\mathrm{S} \mathrm{cm}^{-1}$, is defined as:

$$
\sigma=\left(1 / R_{S}\right) \times(t / A)
$$

where $\mathrm{R}_{\mathrm{S}}$ corresponds to the intercept of the $\mathrm{x}$-axis in the EIS spectrum at high frequency, in $\Omega$; $\mathrm{t}$ the thickness of the gas diffusion layer $\left(0.0381 \mathrm{~cm}\right.$ for Spectracarb ${ }^{\circledR}$ and $0.0325 \mathrm{~cm}$ for Sigracet $\left.{ }^{\circledR}\right)$; A the area of the sample, $1 \mathrm{~cm}^{2}$. The cathode stream was analysed by means of a ThermoStar ${ }^{\mathrm{TM}}$ GSD320 mass spectrometer (Pfeiffer, Ablar, Germany), under dark and light operation (Figure S5).

\subsection{Efficiency of the PEC}

The efficiency of the PEC represents the most important characteristics to assess the cell behavior. The definition of enthalpy and throughput efficiencies has been reported above in Equations (5)-(7).

\section{Conclusions}

The concept of a porous hydrophobic carbonaceous backing layer as a photocathode substrate in a photoelectrolysis cell to get dry hydrogen is here demonstrated for the first time.

The utilisation of carbonaceous gas diffusion layers as photocathode substrates, instead of the usual conductive glass (e.g., FTO) provides several advantages:

(i) higher conductivity,

(ii) easy escape of the produced gas from the cell with lower mass transport constraints,

(iii) dry gas production allowing a system simplification in terms of balance of plant by avoiding or reducing the need of a dehumidification subsystem

(iv) substantially higher performance.

Two different carbonaceous gas diffusion layers based on low cost carbon paper and carbon black, were hydrophobised and studied to achieve the best compromise between hydrophobicity and electrical conductivity.

These new porous hydrophobic substrates were demonstrated as cathodic gas diffusion layers in tandem n- $\mathrm{Fe}_{2} \mathrm{O}_{3} /$ transparent FAA-3 membrane/p-CuO photoelectrolysis cells.

The use of a gas diffusion layer, based on Sigracet $35 \mathrm{BC}{ }^{\circledR}$ with the addition of $7 \mathrm{wt} \%$ of FEP, as a substrate for the photocathode has produced a relevant increase of the enthalpic and throughput efficiencies, in the operative region, doubling the performance of the conventional FTO photocathode substrate-based cell.

The maximum value of the enthalpy efficiency was $1.14 \%$ at $-0.56 \mathrm{~V}$, in the external bias driven cell region, whereas a throughput efficiency value of $1.93 \%$ was achieved at $-0.65 \mathrm{~V}$ bias.

A short-term durability test indicated a good stability of the cell as long as a good hydration of the membrane is assured. The use of the solid anionic membrane separator and ionomer coating over the electrodes, besides providing a practical cell architecture for real applications, may also have a positive effect in protecting the semiconductors' surface against photocorrosion in comparison to the use of caustic solutions as liquid electrolytes.

These results appear very promising and indicate a possible extension of the gas diffusion layer approach to other types of photoelectrochemical cells. 
Supplementary Materials: The following are available online at http://www.mdpi.com/2073-4344/10/11/1319/s1, Figure S1: Photos of photocathode substrates Sigracet 35BC ${ }^{\circledR}$ (on the left) and Sigracet $35 B C^{\circledR}+$ FEP $7 \%$ (on the right) after $0 \mathrm{~s}(\mathrm{a}, \mathrm{b})$ and after $1800 \mathrm{~s}(\mathrm{c}, \mathrm{d})$, Figure S2: XRD pattern of synthesised anodic semiconductor $\mathrm{Fe}_{2} \mathrm{O}_{3}$ deposited on FTO glass and relative JCPDS cards, Figure S3: XRD pattern of synthesised anodic semiconductor $\mathrm{Fe}_{2} \mathrm{O}_{3}+\mathrm{NiFeOx}$ deposited on FTO glass and relative JCPDS cards, Figure S4: Photographs of transparent anionic membrane FAA-3 either dry (a) or wet (b), Figure S5: Mass spectrometry analysis during potentiostatic test (applied cell bias of $-0.6 \mathrm{~V}$ ) of the PEC cell (glass $+\mathrm{FTO}+\mathrm{Fe}_{2} \mathrm{O}_{3}+\mathrm{NiFeOX}+$ ionomer/FAA-3/ionomer $+\mathrm{CuO}+$ Sigracet $35 B C^{\circledR}+$ FEP7\%): H2 ionic current (a) and CO ionic current (b), Figure S6: Schematic sketch (a) and photograph (b) of the photoelectrochemical cell (PEC) with carbonaceous gas diffusion layer as cathode substrate and filter paper to highlight any traces of water (left); (c) photograph of filter paper "post operation", Figure S7: Images of a $60 \mathrm{~cm}$ water column (about $60 \mathrm{mbar}$ ) in a burette placed perpendicular to a CuO/ Sigracet $35 \mathrm{BC}{ }^{\circledR}$ + FEP 7\% sample at the beginning (a), after $1800 \mathrm{~s}$ (b), after $15000 \mathrm{~s}$ (c), Figure S8: SEM images of the outer $\mathrm{NiFeOx}$-coated hematite photoanode surface, before (a) and after (b) the durability test.

Author Contributions: Conceptualisation, A.S.A.; methodology, V.B., R.G. and A.S.A.; synthesis and preparation, S.C.Z., C.L.V., A.C., S.T.; investigation, S.T., C.L.V., A.S.; data curation, S.T.; writing-original draft preparation, S.T.; writing-review and editing, R.G. and A.S.A. All authors have read and agreed to the published version of the manuscript.

Funding: Authors gratefully acknowledge funding from the European Union's Horizon 2020 research and innovation programme under grant agreement no. 760930 (FotoH2 project).

Conflicts of Interest: The authors declare no conflict of interest.

\section{References}

1. Romprasert, S. Energy risk with community management and cost analysis. Int. J. Manag. 2020, 11, 1136-1144. [CrossRef]

2. Castro, M.D.F.; Bragança, L.; Machado, B.; Andrade, J.; Bragança, L. European legislation and incentives programmes for demand Side management. Sol. Energy 2020, 200, 114-124. [CrossRef]

3. Ahmad, T.; Zhang, H.; Yan, B. A review on renewable energy and electricity requirement forecasting models for smart grid and buildings. Sustain. Cities Soc. 2020, 55. [CrossRef]

4. Chen, S.; Kharrazi, A.; Liang, S.; Fath, B.D.; Lenzen, M.; Yan, J. Advanced approaches and applications of energy footprints toward the promotion of global sustainability. Appl. Energy 2020, 261, 114415. [CrossRef]

5. Alimohammadi, H.; Bavani, A.R.M.; Roozbahani, A. Mitigating the Impacts of Climate Change on the Performance of Multi-Purpose Reservoirs by Changing the Operation Policy from SOP to MLDR. Water Resour. Manag. 2020, 34, 1495-1516. [CrossRef]

6. Ranjith Kumar, R.; Elavarasan, G.; Kannan, M.; Karthikeyan, D. Standards for environmental protection in India. Int. J. Sci. Technol. Res. 2020, 9, 319-323.

7. Vecchio, C.L.; Trocino, S.; Zignani, S.C.; Baglio, V.; Carbone, A.; Garcia, M.I.D.; Contreras, M.; Gómez, R.; Aricò, A.S. Enhanced Photoelectrochemical Water Splitting at Hematite Photoanodes by Effect of a NiFe-Oxide co-Catalyst. Catalysts 2020, 10, 525. [CrossRef]

8. Adamopoulos, P.M.; Papagiannis, I.; Raptis, D.; Lianos, P. Photoelectrocatalytic Hydrogen Production Using a TiO2/WO3 Bilayer Photocatalyst in the Presence of Ethanol as a Fuel. Catalysts 2019, 9, 976. [CrossRef]

9. Kalanur, S.S. Structural, Optical, Band Edge and Enhanced Photoelectrochemical Water Splitting Properties of Tin-Doped WO3. Catalysts 2019, 9, 456. [CrossRef]

10. Ennaceri, H.; Fischer, K.; Hanus, K.; Chemseddine, A.; Prager, A.; Griebel, J.; Kühnert, M.; Schulze, A.; Abel, B. Effect of Morphology on the Photoelectrochemical Activity of TiO2 Self-Organized Nanotube Arrays. Catalysts 2020, 10, 279. [CrossRef]

11. Shahrezaei, M.; Hejazi, S.M.H.; Rambabu, Y.; Vavrecka, M.; Bakandritsos, A.; Oezkan, S.; Zboril, R.; Schmuki, P.; Naldoni, A.; Kment, S. Multi-Leg $\mathrm{TiO}_{2}$ Nanotube Photoelectrodes Modified by Platinized Cyanographene with Enhanced Photoelectrochemical Performance. Catalysts 2020, 10, 717. [CrossRef]

12. Yang, Y.; Xie, R.; Liu, Y.; Li, J.; Li, W. Effect of Surface Passivation on Photoelectrochemical Water Splitting Performance of WO3 Vertical Plate-Like Films. Catalysts 2015, 5, 2024-2038. [CrossRef]

13. Tolod, K.R.; Hernandez, S.; Russo, N. Recent Advances in the BiVO4 Photocatalyst for Sun-Driven Water Oxidation: Top-Performing Photoanodes and Scale-Up Challenges. Catalysts 2017, 7, 13. [CrossRef]

14. Hamid, S.B.A.; Teh, S.J.; Lai, C.W. Photocatalytic Water Oxidation on ZnO: A Review. Catalysts 2017, 7, 93. [CrossRef] 
15. Huang, P.-C.; Shen, Y.-M.; Brahma, S.; Huang, J.-L.; Shaikh, M.O.; Wang, S.-C. SnSx $(x=1,2)$ Nanocrystals as Effective Catalysts for Photoelectrochemical Water Splitting. Catalysts 2017, 7, 252. [CrossRef]

16. Zelny, M.; Kment, S.; Ctvrtlik, R.; Paušová, Š.; Kmentová, H.; Tomáštík, J.; Hubička, Z.; Rambabu, Y.; Krýsa, J.; Naldoni, A.; et al. TiO2 Nanotubes on Transparent Substrates: Control of Film Microstructure and Photoelectrochemical Water Splitting Performance. Catalysts 2018, 8, 25. [CrossRef]

17. Joe, J.; Bae, C.; Kim, E.; Ho, T.A.; Yang, H.; Park, J.H.; Shin, H. Mixed-Phase (2H and 1T) MoS2 Catalyst for a Highly Efficient and Stable Si Photocathode. Catalysts 2018, 8, 580. [CrossRef]

18. Nguyen, V.N.; Nguyen, M.V.; Nguyen, T.H.T.; Doan, M.T.; Ngoc, L.L.T.; Janssens, E.; Yadav, A.; Lin, P.-C.; Nguyen, M.S.; Hoang, N.H. Surface-Modified Titanium Dioxide Nanofibers with Gold Nanoparticles for Enhanced Photoelectrochemical Water Splitting. Catalysts 2020, 10, 261. [CrossRef]

19. Li, X.; Liu, A.; Chu, D.; Zhang, C.; Du, Y.; Huang, J.; Yang, P. High Performance of Manganese Porphyrin Sensitized p-Type CuFe2O4 Photocathode for Solar Water Splitting to Produce Hydrogen in a Tandem Photoelectrochemical Cell. Catalysts 2018, 8, 108. [CrossRef]

20. Nakajima, T.; Nakamura, T.; Tsuchiya, T. Crystal-Plane Dependence of Nb-Doped Rutile TiO2 Single Crystals on Photoelectrochemical Water Splitting. Catalysts 2019, 9, 725. [CrossRef]

21. Jozwiak, L.; Balcerzak, J.; Tyczkowski, J. Plasma-Deposited Ru-Based Thin Films for Photoelectrochemical Water Splitting. Catalysts 2020, 10, 278. [CrossRef]

22. Mohamedkhair, A.K.; Drmosh, Q.; Qamar, M.; Yamani, Z.H. Nanostructured Magnéli-Phase W18O49 Thin Films for Photoelectrochemical Water Splitting. Catalysts 2020, 10, 526. [CrossRef]

23. Shaddad, M.N.; Arunachalam, P.; Hezam, M.; Al-Mayouf, A.M. Cooperative Catalytic Behavior of SnO2 and NiWO4 over BiVO4 Photoanodes for Enhanced Photoelectrochemical Water Splitting Performance. Catalysts 2019, 9, 879. [CrossRef]

24. Joe, J.; Yang, H.; Bae, C.; Shin, H. Metal Chalcogenides on Silicon Photocathodes for Efficient Water Splitting: A Mini Overview. Catalysts 2019, 9, 149. [CrossRef]

25. Peng, B.; Xia, M.; Li, C.; Yue, C.; Diao, P. Network Structured CuWO4/BiVO4/Co-Pi Nanocomposite for Solar Water Splitting. Catalysts 2018, 8, 663. [CrossRef]

26. Cots, A.; Bonete, P.; Sebastián, D.; Baglio, V.; Aricò, A.S.; Gómez, R. Toward Tandem Solar Cells for Water Splitting Using Polymer Electrolytes. ACS Appl. Mater. Interfaces 2018, 10, 25393-25400. [CrossRef]

27. He, X.; Boehm, R.F. Direct solar water splitting cell using water, WO3, Pt, and polymer electrolyte membrane. Energy 2009, 34, 1454-1457. [CrossRef]

28. Aricò, A.S.; Girolamo, M.; Siracusano, S.; Sebastián, D.; Baglio, V.; Schuster, M. Polymer Electrolyte Membranes for Water Photo-Electrolysis. Membranes 2017, 7, 25. [CrossRef]

29. Spasov, D.D.; Ivanova, N.A.; Pushkarev, A.S.; Pushkareva, I.V.; Presnyakova, N.N.; Chumakov, R.G.; Presnyakov, M.Y.; Grigoriev, S.; Fateev, V.N. On the Influence of Composition and Structure of Carbon-Supported Pt-SnO2 Hetero-Clusters onto Their Electrocatalytic Activity and Durability in PEMFC. Catalysts 2019, 9, 803. [CrossRef]

30. Daş, E.; Gürsel, S.A.; Yurtcan, A.B. Pt-alloy decorated graphene as an efficient electrocatalyst for PEM fuel cell reactions. J. Supercrit. Fluids 2020, 165, 104962. [CrossRef]

31. Liu, Z.; Chen, J.; Liu, H.; Yan, C.; Hou, Y.; He, Q.; Zhang, J.; Hissel, D. Anode purge management for hydrogen utilization and stack durability improvement of PEM fuel cell systems. Appl. Energy 2020, 275, 115110. [CrossRef]

32. Daniel, L.; Bonakdarpour, A.; Wilkinson, D.P. Benefits of platinum deposited in the polymer membrane subsurface on the operational flexibility of hydrogen fuel cells. J. Power Sources 2020, 471, 228418. [CrossRef]

33. Ren, P.; Pei, P.; Li, Y.; Wu, Z.; Chen, D.; Huang, S. Degradation mechanisms of proton exchange membrane fuel cell under typical automotive operating conditions. Prog. Energy Combust. Sci. 2020, 80, 100859. [CrossRef]

34. Moazeni, F.; Khazaei, J. Electrochemical optimization and small-signal analysis of grid-connected polymer electrolyte membrane (PEM) fuel cells for renewable energy integration. Renew. Energy 2020, 155, 848-861. [CrossRef]

35. Gülen, S.; Rogers, J.; Sprengel, M. DICE-gas turbine compound reheat combined cycle. Fuel 2020, $279,118515$. [CrossRef]

36. Amador, G.; Yepes, H.A.; González-Quiroga, A.; Bula, A. Development of extended formulations of the relative concentration of chain carrier method for knock prediction in spark-ignited internal combustion engines fueled with gaseous fuels. Fuel 2020, 279, 118352. [CrossRef] 
37. Fiore, M.; Magi, V.; Viggiano, A. Internal combustion engines powered by syngas: A review. Appl. Energy 2020, 276, 115415. [CrossRef]

38. Gao, J.; Tian, G.; Ma, C.; Balasubramanian, D.; Xing, S.; Jenner, P. Numerical investigations of combustion and emissions characteristics of a novel small scale opposed rotary piston engine fuelled with hydrogen at wide open throttle and stoichiometric conditions. Energy Convers. Manag. 2020, 221, 113178. [CrossRef]

39. Ram, N.K.; Singh, N.R.; Raman, P.; Kumar, A.; Kaushal, P. Experimental study on performance analysis of an internal combustion engine operated on hydrogen-enriched producer gas from the air-steam gasification. Energy 2020, 205. [CrossRef]

40. Wang, Z.; Roberts, R.; Naterer, G.; Gabriel, K. Comparison of thermochemical, electrolytic, photoelectrolytic and photochemical solar-to-hydrogen production technologies. Int. J. Hydrogen Energy 2012, 37, 16287-16301. [CrossRef]

41. Bensaid, S.; Centi, G.; Garrone, E.; Perathoner, S.; Saracco, G. Towards Artificial Leaves for Solar Hydrogen and Fuels from Carbon Dioxide. ChemSusChem 2012, 5, 500-521. [CrossRef] [PubMed]

42. Ros, C.; Andreu, T.; Morante, J.R. Photoelectrochemical water splitting: A road from stable metal oxides to protected thin film solar cells. J. Mater. Chem. A 2020, 8, 10625-10669. [CrossRef]

43. Tiwari, J.N.; Singh, A.N.; Sultan, S.; Kim, K.S. Recent Advancement of p- and d-Block Elements, Single Atoms, and Graphene-Based Photoelectrochemical Electrodes for Water Splitting. Adv. Energy Mater. 2020, 10. [CrossRef]

44. Zhang, D.; Cao, Y.; Karuturi, S.K.; Du, M.; Liu, M.; Xue, C.; Chen, R.; Wang, P.; Zhang, J.; Shi, J.; et al. Enabling Unassisted Solar Water Splitting by Single-Junction Amorphous Silicon Photoelectrodes. ACS Appl. Energy Mater. 2020, 3, 4629-4637. [CrossRef]

45. Luo, H.; Dimitrov, S.; Daboczi, M.; Kim, J.-S.; Guo, Q.; Fang, Y.; Stoeckel, M.-A.; Samorì, P.; Fenwick, O.; Sobrido, A.B.J.; et al. Nitrogen-Doped Carbon Dots/TiO2 Nanoparticle Composites for Photoelectrochemical Water Oxidation. ACS Appl. Nano Mater. 2020, 3, 3371-3381. [CrossRef]

46. Hu, R.; Wang, X.; Zhang, J.; Hu, D.; Wu, J.; Zhou, R.; Li, L.; Li, M.; Li, D.; Wu, T. Multi-Metal Nanocluster Assisted Cu-Ga-Sn Tri-Doping for Enhanced Photoelectrochemical Water Splitting of BiVO 4 Film. Adv. Mater. Interfaces 2020, 7. [CrossRef]

47. Zappia, M.I.; Bianca, G.; Bellani, S.; Serri, M.; Najafi, L.; Oropesa-Nuñez, R.; Martín-García, B.; Bouša, D.; Sedmidubský, D.; Pellegrini, V.; et al. Solution-Processed GaSe Nanoflake-Based Films for Photoelectrochemical Water Splitting and Photoelectrochemical-Type Photodetectors. Adv. Funct. Mater. 2020, 30. [CrossRef]

48. Xiong, W.; Huang, F.; Zhang, R.-Q. Recent developments in carbon nitride based films for photoelectrochemical water splitting. Sustain. Energy Fuels 2020, 4, 485-503. [CrossRef]

49. Li, Z.; Xu, Z.; Li, D.; Wu, A.; Ruan, R. A nanoporous GaN photoelectrode on patterned sapphire substrates for high-efficiency photoelectrochemical water splitting. J. Alloy. Compd. 2019, 803, 748-756. [CrossRef]

50. Alvi, N.U.H.; Rodriguez, P.E.S.; Hassan, W.U.; Zhou, G.; Willander, M.; Nötzel, R. Unassisted water splitting with $9.3 \%$ efficiency by a single quantum nanostructure photoelectrode. Int. J. Hydrogen Energy 2019, 44, 19650-19657. [CrossRef]

51. Zhang, S.; Shen, L.; Ye, T.; Kong, K.; Ye, H.; Ding, H.; Hu, Y.; Hua, J. Noble-Metal-Free Perovskite-BiVO4 Tandem Device with Simple Preparation Method for Unassisted Solar Water Splitting. Energy Fuels 2020, 34, 5016-5023. [CrossRef]

52. Wang, Y.; Shi, H.; Cui, K.; Zhang, L.; Ge, S.; Yu, J. Reversible electron storage in tandem photoelectrochemical cell for light driven unassisted overall water splitting. Appl. Catal. B Environ. 2020, 275, 119094. [CrossRef]

53. Park, J.; Yoon, K.-Y.; Kimab, T.; Jang, H.; Kwak, M.-J.; Kim, J.Y.; Jang, J.-H. A highly transparent thin film hematite with multi-element dopability for an efficient unassisted water splitting system. Nano Energy 2020, 76, 105089. [CrossRef]

54. Ho, C.H.Y.; Kim, T.; Xiong, Y.; Firdaus, Y.; Yi, X.; Dong, Q.; Rech, J.J.; Gadisa, A.; Booth, R.; O'Connor, B.T.; et al. High-Performance Tandem Organic Solar Cells Using HSolar as the Interconnecting Layer. Adv. Energy Mater. 2020, 10. [CrossRef]

55. Wang, D.; Hu, J.; Sherman, B.D.; Sheridan, M.V.; Yan, L.; Dares, C.J.; Zhu, Y.; Li, F.; Huang, Q.; You, W.; et al. A molecular tandem cell for efficient solar water splitting. Proc. Natl. Acad. Sci. USA 2020, 117, 13256-13260. [CrossRef] 
56. Pham, D.P.; Lee, S.; Le, A.H.T.; Cho, E.-C.; Cho, Y.H.; Yi, J. Monocrystalline silicon-based tandem configuration for solar-to-hydrogen conversion. Inorg. Chem. Commun. 2020, 116, 107926. [CrossRef]

57. Cottre, T.; Welter, K.; Ronge, E.; Smirnov, V.; Finger, F.; Jooss, C.; Kaiser, B.; Jaegermann, W. Integrated Devices for Photoelectrochemical Water Splitting Using Adapted Silicon Based Multi-Junction Solar Cells Protected by ALD TiO2 Coatings. Z. Phys. Chem. 2020, 234, 1155-1169. [CrossRef]

58. Jacobsson, T.J.; Fjallstrom, V.; Edoff, M.; Edvinsson, T. A theoretical analysis of optical absorption limits and performance of tandem devices and series interconnected architectures for solar hydrogen production. Sol. Energy Mater. Sol. Cells 2015, 138, 86-95. [CrossRef]

59. Jiang, C.; Moniz, S.J.A.; Junwang, T.; Zhang, T.; Tang, J. Photoelectrochemical devices for solar water splitting-materials and challenges. Chem. Soc. Rev. 2017, 46, 4645-4660. [CrossRef]

60. Han, B.; Risch, M.; Belden, S.; Lee, S.; Bayer, D.; Mutoro, E.; Shao-Horn, Y. Screening Oxide Support Materials for OER Catalysts in Acid. J. Electrochem. Soc. 2018, 165, F813-F820. [CrossRef]

61. Ghorpade, U.V.; Suryawanshi, M.P.; Shin, S.W.; Kim, J.; Kang, S.H.; Ha, J.-S.; Kolekar, S.S.; Kim, J. Unassisted visible solar water splitting with efficient photoelectrodes sensitized by quantum dots synthesized via an environmentally friendly eutectic solvent-mediated approach. J. Mater. Chem. A 2018, 6, 22566-22579. [CrossRef]

62. Massué, C.; Pfeifer, V.; Huang, X.; Noack, J.; Tarasov, A.; Cap, S.; Schlögl, R. High-Performance Supported Iridium Oxohydroxide Water Oxidation Electrocatalysts. ChemSusChem 2017, 10, 1943-1957. [CrossRef] [PubMed]

63. Wang, X.-D.; Xu, Y.-F.; Chen, B.-X.; Zhou, N.; Chen, H.-Y.; Kuang, D.-B.; Su, C.-Y. 3D Cathodes of Cupric Oxide Nanosheets Coated onto Macroporous Antimony-Doped Tin Oxide for Photoelectrochemical Water Splitting. ChemSusChem 2016, 9, 3012-3018. [CrossRef] [PubMed]

64. Hufnagel, A.G.; Peters, K.; Müller, A.; Scheu, C.; Fattakhova-Rohlfing, D.; Bein, T. Zinc Ferrite Photoanode Nanomorphologies with Favorable Kinetics for Water-Splitting. Adv. Funct. Mater. 2016, 26, 4435-4443. [CrossRef]

65. Wang, D.; Zhang, Y.; Peng, C.; Wang, J.; Huang, Q.; Su, S.; Wang, L.; Huang, W.; Fan, C. Crystallinity Engineering of Hematite Nanorods for High-Efficiency Photoelectrochemical Water Splitting. Adv. Sci. 2015, 2, 1500005. [CrossRef] [PubMed]

66. Kondofersky, I.; Dunn, H.K.; Müller, A.; Mandlmeier, B.; Feckl, J.M.; Fattakhova-Rohlfing, D.; Scheu, C.; Peter, L.M.; Bein, T. Electron Collection in Host-Guest Nanostructured Hematite Photoanodes for Water Splitting: The Influence of Scaffold Doping Density. ACS Appl. Mater. Interfaces 2015, 7, 4623-4630. [CrossRef]

67. Mierzwa, M.; Lamouroux, E.; Walcarius, A.; Etienne, M. Porous and Transparent Metal-oxide Electrodes: Preparation Methods and Electroanalytical Application Prospects. Electroanalysis 2018, 30, 1241-1258. [CrossRef]

68. Carbone, A.; Zignani, S.C.; Gatto, I.; Trocino, S.; Aricò, A.S. Assessment of the FAA3-50 polymer electrolyte in combination with a NiMn2O4 anode catalyst for anion exchange membrane water electrolysis. Int. J. Hydrogen Energy 2020, 45, 9285-9292. [CrossRef]

69. Lee, M.; Huang, X. An improved hydrophobic coating for the porous gas diffusion layer in a PEM-based electrochemical hydrogen pump to mitigate anode flooding. Electrochem. Commun. 2020, 117, 106777. [CrossRef]

70. Kannan, A.; Li, Q.; Cleemann, L.N.; Jensen, J.O. Acid Distribution and Durability of HT-PEM Fuel Cells with Different Electrode Supports. Fuel Cells 2018, 18, 103-112. [CrossRef]

71. Bevilacqua, N.; George, M.; Galbiati, S.; Bazylak, A.; Zeis, R. Phosphoric Acid Invasion in High Temperature PEM Fuel Cell Gas Diffusion Layers. Electrochim. Acta 2017, 257, 89-98. [CrossRef]

72. Bevilacqua, N.; George, M.G.; Bazylak, A.; Zeis, R. Phosphoric acid distribution patterns in high temperature PEM fuel cells. ECS Trans. 2017, 80, 409-417. [CrossRef]

73. Chevalier, S.; Fazeli, M.; Mack, F.; Galbiati, S.; Manke, I.; Bazylak, A.; Zeis, R. Role of the microporous layer in the redistribution of phosphoric acid in high temperature PEM fuel cell gas diffusion electrodes. Electrochim. Acta 2016, 212, 187-194. [CrossRef]

74. Rastedt, M.; Pinar, F.J.; Pilinski, N.; Dyck, A.; Wagner, P. Effect of operation strategies on phosphoric acid loss in HT-PEM fuel cells. ECS Trans. 2016, 75, 455-469. [CrossRef]

75. European Commission. Fourth List of Critical Raw Materials for the EU of 2020. Available online: https://ec.europa.eu/growth/sectors/raw-materials/specific-interest/critical_en (accessed on 30 October 2020). 
76. Grätzel, M. Photoelectrochemical cells. Nat. Cell Biol. 2001, 414, 338-344. [CrossRef]

77. Khaselev, O. A Monolithic Photovoltaic-Photoelectrochemical Device for Hydrogen Production via Water Splitting. Science 1998, 280, 425-427. [CrossRef]

78. Bak, T.; Nowotny, J.; Rekas, M.; Sorrell, C. Photo-electrochemical hydrogen generation from water using solar energy. Materials-related aspects. Int. J. Hydrog. Energy 2002, 27, 991-1022. [CrossRef]

79. Zignani, S.C.; Faro, M.L.; Trocino, S.; Aricò, A.S. Investigation of NiFe-Based Catalysts for Oxygen Evolution in Anion-Exchange Membrane Electrolysis. Energies 2020, 13, 1720. [CrossRef]

80. Cots, A.; Cibrev, D.; Bonete, P.; Gómez, R. Hematite Nanorod Electrodes Modified with Molybdenum: Photoelectrochemical Studies. ChemElectroChem 2017, 4, 585-593. [CrossRef]

81. Aricò, A.S.; Gullo, L.R.; La Rosa, D.; Diracusano, S.; Tavares, A.B.L.C.; Xicola, A.S. Solid Oxide Fuel Cell with Cermet Cu/Ni Alloy Anode. Patent WO 2004/049491, 10 June 2004.

82. Carbone, A.; Pedicini, R.; Gatto, I.; Saccà, A.; Patti, A.; Bella, G.; Cordaro, M. Development of Polymeric Membranes Based on Quaternized Polysulfones for AMFC Applications. Polymers 2020, 12, 283. [CrossRef] [PubMed]

Publisher's Note: MDPI stays neutral with regard to jurisdictional claims in published maps and institutional affiliations.

(C) 2020 by the authors. Licensee MDPI, Basel, Switzerland. This article is an open access article distributed under the terms and conditions of the Creative Commons Attribution (CC BY) license (http://creativecommons.org/licenses/by/4.0/). 